\title{
From mice to men: lessons from mutant ataxic mice
}

\author{
Jan Cendelin ${ }^{1,2}$
}

\begin{abstract}
Ataxic mutant mice can be used to represent models of cerebellar degenerative disorders. They serve for investigation of cerebellar function, pathogenesis of degenerative processes as well as of therapeutic approaches. Lurcher, Hot-foot, Purkinje cell degeneration, Nervous, Staggerer, Weaver, Reeler, and Scrambler mouse models and mouse models of SCA1, SCA2, SCA3, SCA6, SCA7, SCA23, DRPLA, Niemann-Pick disease and Friedreich ataxia are reviewed with special regard to cerebellar pathology, pathogenesis, functional changes and possible therapeutic influences, if any. Finally, benefits and limitations of mouse models are discussed.
\end{abstract}

Keywords: Ataxia, Cerebellum, Neurodegeneration

\section{Introduction}

The cerebellum is a part of the brain that participates in many complex functions. It is involved not only in motor coordination and motor learning but it also plays a role in cognitive and affective functions. Therefore manifestations of cerebellar dysfunction includes motor deficits as well as mental and behavioral abnormalities known in humans as cognitive-affective syndrome [1]. The three main motor signs of cerebellar disorder are ataxia, tremor and increased muscle passivity. These result in many motor problems including ataxic gait and posture, deterioration of goal-directed movements of the extremities, eyeball movement abnormalities, speech disorders, etc. The cerebellum can be damaged due to injuries, ischemia, hemorrhage, tumors, inflammation, intoxication and inherited neurodegenerative conditions. Humans are afflicted with a wide spectrum of hereditary cerebellar degenerations [2], for which, presently, there is no effective causal therapy. The main therapeutic approach is intensive rehabilitation directed toward helping patients improve motor abilities and learning to live with the disease.

Variability of human hereditary cerebellar degenerative disorders is also reflected in animal models of cerebellar

\footnotetext{
Correspondence: jan.cendelin@lfp.cuni.cz

${ }^{1}$ Department of Pathophysiology, Faculty of Medicine in Pilsen, Charles University in Prague, Lidicka 1, 30166 Plzen, Czech Republic

${ }^{2}$ Biomedical Centre, Faculty of Medicine in Pilsen, Charles University in ${ }^{2}$ Biomedical Centre, Faculty of
Prague, Plzen, Czech Republic
}

ataxias [3]. Mouse models of cerebellar degenerations are either spontaneous mutants or transgenic animals. For some genes there are spontaneous or induced mutations as well as transgenic mouse models. Mouse models of hereditary cerebellar degenerative disorders are used to investigate symptoms, pathogenesis, and cell death mechanisms, as well as to develop and test therapeutic approaches for these diseases. Elucidation of the relationships between functional abnormalities and cerebellar defects could further our understanding of cerebellar function. Since there are complex interconnections between the cerebellum and other areas of the central nervous system and since degeneration, in many cases, is in not restricted to just the cerebellum, a more complete knowledge of the features of individual cerebellar ataxic mice is important for selection of appropriate models for particular studies and for appropriate interpretation of findings. The cerebellar degenerative disorders seen in mice show some similarities with those seen in human patients, although there are also certain differences that limit their research applications. All these fact should be taken into account when choosing and using a mouse model for cerebellar ataxia. The aim of this review is to describe the main types of cerebellar ataxic mice with special regard to cerebellar pathology, pathogenesis, functional changes and possible therapeutic influences, if any, and to discuss their benefits and limitations relative to research applications. 


\section{Review}

\section{Classic cerebellar mutant mice Lurcher mice}

Lurcher mice are well studied spontaneous cerebellar mutants. They were first described in 1960 by Phillips [4]. The degeneration is caused by a semi-dominant mutation $\left(G r i d 2^{L c}\right)$ in the $\delta 2$ glutamate receptor (GluR $\left.\delta 2\right)$ encoding a gene localized on chromosome $6[4,5]$. GluR $\delta 2$ receptors are expressed at high levels in cerebellar Purkinje cells [6]. The Grid2 $2^{L c}$ mutation is a gain of function mutation, which changes the receptor into a leaky membrane channel that chronically depolarizes the cells [5]. Later, a second Lurcher allele $\left(L c^{J}\right)$, which is phenotypically indistinguishable from $\operatorname{Grid} 2^{L c}$, was found in an inbred strain BALB/cByJ [7].

Homozygous Lurcher mice (Grid2 $2^{L c / L c}$ ) die shortly after birth due to the massive loss of mid- and hindbrain neurons during late embryogenesis and the inability to suck for milk after birth [8]. Heterozygous Lurcher mice are viable with normal lifespans and suffer from postnatal degeneration of cerebellar Purkinje, granule, stellate and basket cells and inferior olive neurons $[9,10]$.

Heterozygous Lurcher Purkinje cell reduction can be detected by about postnatal (P) day 8-10 [9]. The progress of degeneration varies between individual cerebellar lobules [11]. About 95\% of Purkinje neurons die between P8 and P25 and virtually all of them have degenerated by P90 [9]. The several hundred surviving Purkinje cells are restricted to the paraflocculus, flocculus and the nodular zone and can be detected as late as P146 [11].

The death of Lurcher mutant Purkinje cells is cell autonomous and it is a primary effect of the mutation $[12,13]$. The Purkinje cells show high membrane conductance and a depolarized resting potential due to the presence of a large inward $\mathrm{Na}^{+}$current [5]. This state of permanent cell excitation and over-activation of $\mathrm{Na}^{+}-\mathrm{K}^{+}$ ATPase probably leads to increased energy demand, decreased intracellular ATP levels [14] and increased mitochondrial cytochrome oxidase activity [15].

Zuo et al. [5] suggested excitotoxic apoptosis as the mechanism of Purkinje cell death in Lurcher mice. Norman et al. [16] observed swelling of axons, chromatin condensation, cell and nuclear membrane blebbing in Lurcher mutant Purkinje neurons, glial cell processes wrapped around dying Purkinje neurons, ready to engulf their remnants. They also observed apoptotic bodies which had already been engulfed by glial cells and the absences of infiltration with leucocytes, which indicated cell death through apoptosis [16]. Deformation of cell shape and nuclei, thickened dendrites, irregular staining of nuclei and cytoplasm and increased numbers of nucleoli in degenerating Lurcher Purkinje cells were also found [17]. Increase in pro-caspase 3 expression, in Lurcher mutant Purkinje cells, may participate in the induction of apoptosis [18]. On the other hand, ultrastructural signs, such as axonal swellings and torpedoes, perinuclear clumps of chromatin and enlarged mitochondria with dilated cristae indicate necrotic cell death $[19,20]$. Finally, evidence for autophagic pathways in Lurcher Purkinje cells was also found. Yue et al. [21] reported that dying Lurcher Purkinje cells contain morphological hallmarks of autophagic death in vivo. Later, Wang et al. [22] described accumulation of autophagosomes in axonal dystrophic swellings of Lurcher Purkinje cells. Nishiyama and Yuzaki [14] reevaluated Purkinje cell degeneration in Lurcher mice and designated it as necrosis with autophagic features. Zanjani et al. [23] found that in vitro inhibition of conventional protein kinase $\mathrm{C}$, c-Jun $\mathrm{N}$-terminal kinase, as well as p38, led to enhanced survival of Lurcher mutant Purkinje cells in cerebellar slices suggesting that multiple Purkinje cell death pathways are induced in Lurchers.

Degeneration of granule cells is also fast but not complete. By P60 almost $90 \%$ of granule cells are lost [9]. As mentioned above, the number of Golgi, stellate and basket cells are also reduced [10]. Loss of inferior olive neurons becomes apparent by P11 and represents about $70-75 \%$ of the complete neuronal population [9]. Reduction of granule cells and inferior olive neurons is targetrelated cell death and can be prevented by surviving Purkinje cells in Lurcher-wild type chimeras [12,13,24]. Stellate and basket cells are probably also affected through a target-related cell death mechanism since there is no evidence that the Grid2 receptor is expressed in cerebellar interneurons [10]. Degeneration of the deep cerebellar nuclei is relatively mild in Lurchers [25-27].

Lurcher mice exhibit multiple abnormalities of neural functions. The main and most evident symptom of cerebellar degeneration is ataxia with a wobbly, lurching gait and irregular EMG pattern during walking [28]. Lurchers show poor performance on the treadmill test [29], rotarod test [30-33], static wooden beam [33], unstable platform [34], vertical grid [30,35], horizontal bar or coat-hanger test $[30,32]$. Nevertheless, on some tests, improvement was seen in their motor performance when repeating the task $[31,36,37]$. Lurcher mice show a decline in motor skills [38], motor learning [37] and spatial learning ability [39] with ageing. Lurcher mice also suffer from disorder and lack of adaptive modifications in the oculomotor system [40].

Lurcher mutant mice do poorly on cognitive function tests. Despite this, they show some level of learning ability in the standard Morris water maze test with a hidden platform, although their escape latencies are longer than those of wild type mice [41-43]. Lurchers also have difficulty in guiding themselves, in the water maze, toward a visible goal, which suggests that their deficit in visuomotor coordination contributes to their spatial orientation impairment 
$[41,44]$ Lurchers also exhibit deficits in long-term memory [45]. Porras-Garcia et al. $[42,46]$ described changes in classical conditioning of eyelid responses in Lurcher mice. Lurchers show higher spontaneous activity than control wild type mice [47], however, their exploration behavior on the hole-board test is reduced $[35,47,48]$.

While basal levels of both adrenocorticotropic hormone and corticosterone are similar in Lurcher mutants and control mice, mutants show hyper-reactivity of the hypothalamic-pituitary-adrenal axis [49,50]. Hilber et al. [50] observed that exposure to an anxiogenic situation (elevated plus-maze) increased corticosterone levels more in the mutants than in controls. However, Lurchers showed reduced behavioral indices of anxiety, which suggests that they are rather less inhibited than less anxious [50]. This agrees with observation that Lurchers have lower prepulse inhibition, as described by Porras-Garcia et al. [42]. Nevertheless, stress-provoked high corticosterone levels cause only part of the behavioral disinhibition, since inhibition of corticosterone synthesis produced only modest changes in anxiety-related behaviors in Lurchers [51]. Lurcher females have a high incidence of maternal infanticide, which could be triggered by anxiogenic stimuli linked to their behavioral disinhibition [52].

Furthermore, tests of behavioral flexibility in Lurcher mice and chimeras, between Lurcher heterozygous and wild type individuals, suggested that developmental cerebellar Purkinje cell loss may affect higher level cognitive processes that are commonly deficient in autism spectrum disorders [53]. In Lurcher mice, evoked glutamate release is decreased in the mediodorsal and ventrolateral thalamic nuclei, reticulotegmental nuclei and pedunculopontine nuclei [54]. This is a mechanism by which Purkinje cell loss could disrupt glutamate release in cerebellar efferent pathways that ultimately affects dopamine release in the prefrontal cortex associated with autism spectrum disorders [54].

\section{Hotfoot mice}

Hotfoot mice have mutation (Grid $2^{h o}$ ) in the $\delta 2$ glutamate receptor (GluR $\delta 2)$ encoding gene on chromosome 6, the same gene, which is affected in Lurcher mice [55]. Several alleles causing the Hot-foot phenotype have been discovered [56,57]. While the Grid2 ${ }^{L c}$ (Lurchers) is a gain of function mutation, the Grid2 $2^{\text {ho }}$ is a loss of function mutation leading to retention of the GluR $\delta 2$ in the endoplasmic reticulum and thus its absence on the cell surface [58].

Anatomical alterations are relatively mild; the most obvious being Purkinje cells with ectopic spines devoid of presynaptic innervations $[59,60]$. The Hotfoot phenotype is characterized by a flattened body posture, wide base, backing up and jerky movements of the hind limbs [59]. Hotfoot mice do poorly on the rotating grid, wooden beam, coat hanger and rotarod tests, however, they showed evidence of learning in the rotating grid and coat hanger tests, but not on the wooden beam and rotarod $[31,36,61]$. They did not alternate above chance in the T-maze and failed in the Z-maze test [62].

\section{Purkinje cell degeneration mice}

Purkinje cell degeneration (pcd) mice are one of the most frequently used spontaneous cerebellar mutants. The heredity of the disorder is autosomal recessive with full penetrance [63]. Pcd mice are homozygous for the $A g t p b p 1^{p c d / J}$ mutations in the gene encoding cytosolic ATP/GTP binding protein 1 (synonyms: cytosolic carboxypeptidase-like protein, CCP1, Nna1) located on chromosome 13 [64]. Several spontaneous mutant alleles

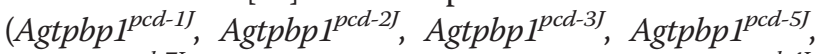
$\left.A g t p b p 1^{p c d-7 J}\right)$ and induced mutations (Agtpbp $1^{p c d-4 J}$,

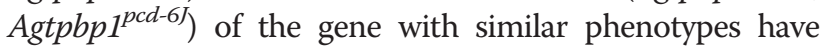
been discovered or generated, respectively. CCP1 is a metallopeptidase that plays a role in peptide turnover. In normal mice it is intensively expressed in cerebellar Purkinje cells, olfactory bulb mitral cells and retinal photoreceptors [64]. Therefore, pcd mice postnatally lose virtually all Purkinje cells and suffer from slow, progressive degeneration of the retina and olfactory bulb mitral cells.

The primary cerebellar pathology in pcd mutants is the loss of Purkinje cells. On P15 the number of Purkinje cells is still within normal range, however, they have already started to show structural abnormalities [65]. Purkinje cell loss starts at P20 and by P25 it has already become massive [66]. By P28 it is nearly complete in most parts of the cerebellum except for the most ventral areas, where numerous Purkinje neurons still remain [63]. Only a few Purkinje cells remain in the nodulus after 7 weeks [63].

Kyuhou et al. [67] suggested that the death of Purkinje cells is apoptotic via the activation of caspase 3. Chakrabarti et al. [68] later described increased autophagy in Purkinje cells. Berezniuk and Fricker [69] suggested that the lack of CCP1 leads to decreased levels of cellular amino acids, which then induce increased autophagy. This could be a protective response to cellular amino acid starvation. They also reported increased autophagy in brain structures, which do not undergo degeneration in pcd mice [70]. CCP1 has also been shown to catalyze shortening of glutamate side chains on polyglutamylated brain tubulin $[71,72]$. Hyperglutamylation resulting from the loss of the function of the enzyme in pcd mice has been suggested to be the primary cause of the degeneration [71].

The degeneration of cerebellar granule cells is secondary to the loss of Purkinje neurons and is exponentially progressive [73,74]. The moderate reduction in the size of deep cerebellar nuclei in older mutants is probably 
due to loss of synaptic input from Purkinje cells [75]. Inferior olivary neurons start to disappear between P17 and P23 and by P300 the reduction has reached 49\% [73]. The degeneration is probably due to the loss of their postsynaptic targets, i.e. Purkinje cells [73]. Degeneration of Purkinje cells is followed by activation of microglia and astrocytes in the cerebellum and apoptotic death of cerebellar oligodendrocytes [66,67].

Olfactory bulb fiber degeneration starts at 13 weeks and at 38 weeks it is massive. Older animals lose mitral cells in the olfactory bulb [63]. Degeneration of the thalamus has also been observed in the brain of pcd mice. Rapid degeneration between P50 and P60 affects the majority of neurons in the central division of the mediodorsal nucleus, ventral medial geniculate, posterior ventromedial and submedial nuclei and those parts of the ventrolateral and posteromedial nuclei surrounding the medial division of the ventrobasal complex [76]. Subtle changes were also found in other thalamic nuclei [76].

Retinal degeneration is manifested by pycnotic nuclei of photoreceptors at 3 weeks in homozygous pcd mice; $50 \%$ of the photoreceptors are gone by the fifth week and the remaining photoreceptors are gone within one year [77-79]. The progress of degeneration is mirrored by decline in retinal function [80].

Pcd mice have reduced bodyweight $[63,81]$ and poor overall health. Pcd males are sterile due to low concentrations, low motility and abnormally formed sperm [63]. Females are not sterile, however their fertility is reduced and they have difficulties rearing pups.

The major neurological symptom in pcd mice is cerebellar ataxia that becomes apparent around P21 $[63,81]$. Pcd mice perform poorly on the coat-hanger and rotarod tests but perform well on the rectangular as well as round stationary beam [82]. Goodlett et al. [81] reported that pcd mice were unable to navigate to a hidden goal in the Morris water maze but had good performances on visual guidance tasks. This finding shows that pcd mice are able to navigate to visible goals, but spatial navigation based on multiple distal cues is severely impaired [81]. Pcd mice show deterioration of delayed eye-blink classical conditioning [83] but not the trace one [84].

Although the Agtpbp $1^{p c d / J}$ mutation is known to be recessive, it has mild effect on Purkinje cells also in heterozygous individuals. At P150 there are no differences in Purkinje cell number between wild type and heterozygous pcd mice, however, by P300 there is $20 \%$ reduction in heterozygotes [85]. Doulazmi et al. [86] reported a similar (18\%) reduction at 17 months, in heterozygous pcd mice. This mild degeneration has been shown to promote fusion of surviving Purkinje cells with grafted bone marrow-derived cells [85].

\section{Nervous mice}

Nervous mice are autosomal recessive mutants suffering from a severe degeneration of Purkinje cells. The nervous mutation $(n r)$ is located on chromosome 8 [87,88]. The Nervous phenotype shows incomplete penetrance and the existence of a nervous modifier locus on mouse chromosome 5 is supposed [88].

On P9 abnormal rounded mitochondria appear in some Purkinje cells and by P15 abnormal mitochondria are present in all Purkinje cells [89]. Later, most of the cells display progressive degenerative changes in the rough endoplasmic reticulum, Golgi complex and polysomes. As late as P23 the number of the Purkinje cells is still almost normal, however, rapid degeneration follows and by P50 $80 \%$ of Purkinje cells in the vermis, $88 \%$ along the vermis-hemisphere junction and $97 \%$ in the hemispheres are gone [89]. Although every nervous Purkinje cell has spherical mitochondria, $10 \%$ of the Purkinje cells do not degenerate and their mitochondria reacquire normal shape [89]. Purkinje cell necrosis is mediated by tissue plasminogen activator, levels of which are elevated in the cerebellum of homozygous nervous mutant mice [90,91]. As a consequence of Purkinje cell loss, one third of the inferior olive neurons undergo retrograde degeneration [92]. Berrebi and Mugnaini [93] described alterations in the dorsal cochlear nuclei of Nervous mice that were similar to those seen in Purkinje cells and reported that although most of the cartwheel cells of the nuclei survive, they show abnormal mitochondria throughout adulthood.

Nervous mutant mice are characterized by their hyperactivity and ataxia [94]. They show impairment on the stationary beam, coat-hanger, and rotarod tests of motor coordination, impairment on the submerged platform, but not the visible platform, Morris water maze task and with higher levels of motor activity in an automated chamber but normal activity on the open field test [94]. The phenotype of nervous mice also includes lower body weight than wild type mice with the same background [94].

The Nervous mutation also leads to retinal degeneration [95]. Photoreceptors degenerate rapidly between P13 and P19, and then degeneration slows [96]. By 7.5 months the outer nuclear layer of the retina consists only of a single row of nuclei, most of which are lost later so that in 17 months old mice only a few photoreceptors remain [96].

\section{Staggerer mice}

The Staggerer is an autosomal recessive mutation (Rora ${ }^{s g}$ ) in the gene encoding the retinoid-related orphan receptor alpha on chromosome 9 [97]. In their first description Staggerer mice were characterized by a staggering gait, tremor hypotonia, small body size and a cerebellar 
cortex having few granule cells and unaligned Purkinje cells [98].

Development of Purkinje cell spines is delayed in Staggerers. The spines appear later on both the cell soma and dendrites and their density is lower [99]. Cytological appearance and degeneration of Purkinje cells is regionally variable and by P30 between 60\% and 90\% are gone [100]. Surviving Purkinje cell somata and dendrites are smaller, ectopic and the dendrites are not confined to the sagittal plane [101,102]. The regional variability of Purkinje cells along the mediolateral axis seems to correspond with variability in calbindin expression [103]. The external granular layer is thinner and the number of postmitotic granule cells is reduced by P21 and almost all granule cells have degenerated by P28 [101]. Staggerer mice lack synapses between Purkinje cells and parallel fibers before granule cells disappear. On the other hand, regression of multiple innervations of Purkinje cells, by climbing fibers, fails and so several of these fibers synapse with each Purkinje cell instead of a single one as in normal mice [104,105].

A study using Staggerer-wild type chimeras revealed that in the Staggerer-genotype medium-to-large neurons in the cerebellum expressed all the defects present in homozygous Staggerer mice, while genotypically wild type Purkinje cells had a normal appearance, suggesting that Purkinje cell defects are cell-intrinsic [102,106]. On the other hand, Staggerer granule cells were rescued in the chimeras and their number had a linear relationship with the number of Purkinje cells, thus granule cell death is an indirect consequence of the mutation $[24,107,108]$.

Deep cerebellar nuclei, despite being reduced in volume by $30 \%$ have normal numbers of neurons $[109,110]$. There is also marked disorganization and loss of almost $60 \%$ of the cells within the inferior olivary complex due to target-related cell death, which is secondary to the degeneration of Purkinje cells [111]. Despite the Rora ${ }^{\text {sg }}$ mutation being described as a recessive mutation, heterozygous mutants, at 12 months, have undergone degeneration of $35 \%$ of Purkinje cells, $35 \%$ of granule cells and $40 \%$ of inferior olive neurons [112]. The Rora ${ }^{s g}$ mutation also influences neuronal differentiation and development in the hippocampal dentate gyrus as shown by a lower expression of doublecortin and NeuN [113].

Staggerer mice display an enhanced endocrine response to novelty stress, which lacks the diurnal shift in corticosterone nonstress levels [114]. Staggerers have multiple behavioral and motor abnormalities. They have an unsteady gait, shorter fall latencies on the wooden beam, grid [115] and rotarod tests [116]. On the rotating grid, wooden beam and coat hanger tests, Staggerer mice had worse performances than wild type controls and they were not able to improve when the tasks were repeated for 7 days [31]. They performed poorly on the radial arm maze and active avoidance tasks [117]. Staggerer mice had fewer hole visits in the hole board test [115]; however, they explored novel objects in a familiar environment for longer times [118] and showed a tendency to return to the place in a maze that they had most recently visited, probably due to abnormal novelty reactions [119]. Since their cerebellum is already abnormal at birth, newborn Staggerers are less efficient in specific motor tasks, have lower body weight and differ from wild type mice in ultrasound production [120].

\section{Weaver mouse}

Weaver mice are semi-dominant mutants carrying the missense $\mathrm{Grik}^{W v}$ mutation of the gene encoding a G-protein coupled with inward rectifying potassium channel and located on chromosome 2 [121]. The mutation results in a disorganized cerebellar structure [122,123] and also affects several extra-cerebellar brain areas.

By the time the pups are born, cell death is detectable in the external granular layer of both homozygous and heterozygous Weaver mice [124]. After birth, abnormalities develop dramatically when the granule cells begin to migrate, so that by P10 developmental defects are markedly present [123]. At this age, the cerebellum of heterozygous Weaver mice is reduced by $5-10 \%$, the granular layer is thinner, while the external granular layer is disarranged and wider than in wild type mice and Purkinje cells are less strictly aligned [123]. The molecular layer is narrower, but shows a greater density of cell bodies because it contains young granule cells [123]. Those cells having a typical soma are properly aligned with normal Bergmann glial fibers, many of the anomalous cells lie contiguous with abnormal glial processes and cells that have lost contact with glial cells are usually seen in various stages of degeneration [123]. In homozygous Weaver mice, cerebellar abnormalities are much more pronounced. The external granular layer is indistinct, granule cells form irregular vertical stacks and many of them have degenerated and Purkinje cells are arranged in several rows and have randomly oriented dendritic trees [123,125]. As in Staggerer mice, Weaver mice Purkinje cells receive multiple innervations from climbing fibers [126]. Later in life cerebellar cytoarchitecture improves somewhat in heterozygous Weaver mice, while most of the homozygotes die around weaning time [123].

Contrary to Lurcher, pcd and Nervous mice, Purkinje cell loss is mild in Weavers. Heterozygotes have $86 \%$ and homozygotes $72 \%$ of the normal number of Purkinje cells [127]. The reduction in the number of Purkinje neurons, as well as granule cells, is more severe in the medial parts of the cerebellum than in lateral areas of the hemispheres [128]. Homozygous Weaver mice suffer from a $20-25 \%$ decrease in the number of deep cerebellar 
nuclei neurons [129]. The inferior olive of both homozygous and heterozygous weaver mice is normal, olivocerebellar projections have a normal topographic organization [127] and most cerebellar afferent pathways appear to be unchanged [130,131]. On the other hand, Ozaki et al. [132] described degeneration of pontine nuclei neurons and retraction of mossy fibers from the cerebellar cortex.

The fact, that degenerating granule cells had abnormal or no contact with Bergmann glia led to the suggestion that the degeneration and reduced rate of migration of granule cells is secondary to a disorder of Bergmann glial cells $[123,133]$. Later studies on chimeric mice revealed that while ectopic Purkinje cells were of both Weaver and non-Weaver origin, all ectopic granule cells were from the weaver component of the chimera, thus the abnormality seen in granule cells is intrinsic and a direct effect of the Grik ${ }^{W v}$ mutation [134]. Furthermore, degeneration affects Weaver Purkinje cells but not non-Weaver Purkinje cells, indicating that while the disorganization of Purkinje cells is an indirect effect, their degeneration is a direct result of the Grik ${ }^{W v}$ mutation [135].

Despite the absence of parallel fibers, Weaver Purkinje cells have normal initial development of both somatic and dendritic spines [136]. They grossly resemble normal Purkinje cells electrophysiologically, when the only qualitative difference is in response to acetylcholine, which increases their firing rate instead of having its usual inhibitory effect [137].

Besides the cerebellum, changes in several other areas of the CNS have been found in Weaver mutants. Cell loss has been described in the pars compacta of the substantia nigra, ventral tegmental area and the retrorubral nucleus [138-140]. In the hippocampus of homozygous Weaver mice, a thicker pyramidal cell layer in the CA3 area with cell-free spaces, ectopic clusters of pyramidal cells, on occasions subdivision of the pyramidal cell layer into 2-3 layers and disorganized mossy fiber projections have been described [141]. The retinas of adult Weaver mice contain more dopaminergic cells, some of which have an abnormal appearance and location [142]. Retinopetal tyrosine hydroxylase-immunoreactive fibers are also dramatically increased in number [143].

Weaver mutants do poorly on the spatial navigation in the water maze test [144]. In the forced swimming task, they did not acquire the immobility response, which was seen wild type mice [145]. Weaver mice had less exploratory activity on the hole board test and shorter fall latencies on the wooden beam and grid tests [146]. They also showed learning deficits [147]. Like some other cerebellar mutations, the Grik ${ }^{W v}$ mutation leads to male sterility due to the death of germ cells in the testes of homozygous males [148].

Motor performance of Weaver mutants has been shown to improve after removal of the cerebellum, which eliminated the faulty output of the surviving Purkinje cells [149]. This suggests that dysfunctional Purkinje cells can be worse than no Purkinje cells at all. Granule cells death has been identified as being apoptotic [150,151]. In vitro studies showed that Weaver granule cells can be rescued by pharmacological blockade of sodium influx [152], with the calcium channel blocker verapamil, with high concentrations of the glutamate receptor antagonist MK-801, using antibodies against the B2 chain of laminin [153] and by protease inhibitors [154]. Nevertheless, removal of tissue plasminogen activator, a serine protease, which is elevated in the cerebellum of Weaver mice, did not protect against the degeneration of granule cells [155]. Overexpression of insulin-like growth factor-I was found to protect Weaver granule cells in vivo, improve muscle strength and alleviate ataxia [156].

\section{Reeler mouse}

Reeler mice [157] have an autosomal recessive $\operatorname{Reln}^{r l}$ mutation on chromosome 5 [158]. The gene encodes the extracellular matrix protein reelin, which is important for neural cell migration [159]. The mutation leads to disordered neuron migration during CNS development resulting in architectonic disorganization and ectopic cell localization in the cerebellum $[160,161]$, hippocampus [162,163], neocortex [164], inferior olive [165], olfactory bulb [166], cochlear nucleus [167], superior colliculus [168] and substantia nigra [169]. The characteristic feature of the Reeler brain cortex is an inversion of the layers and cells [170]. Nevertheless, most of the structures are appropriately interconnected [171-175].

The cerebellum of homozygous Reeler mice is reduced in size [176]. Since embryonic day 17, foliation of the cerebellum becomes deficient [177]. A study of the histological structure of the Reeler cerebellum revealed deep alteration of the cerebellar cortex architecture consisting of out of place Purkinje cells in various locations, lower density of granule cells, lower density of synaptic contacts between Purkinje cells and parallel, climbing and mossy fibers and basket cells $[176,178,179]$. Purkinje cells are reduced to slightly less than half the normal number and only $5 \%$ of the surviving ones are positioned normally, i.e. located between the molecular and granular layers, while $10 \%$ are located within the granular layer and the majority are in characteristic subcortical cellular masses [180]. Some granule cells are retained in the molecular layer. Their axons have an abnormal course and in some cases have no T-like bifurcation [181]. The distribution of fibers within the white matter and their arborization are changed as a result of the cerebellar architecture disorganization [182]. Despite all the above mentioned disarrangement, the specificity of most of the connections is preserved [176]. Some abnormalities, however, have been discovered: (1) deep 
Purkinje cells receiving several climbing fibers, (2) ectopic somato-dendritic or dendro-dendritic synapses between granule and Purkinje cells and (3) synapses between mossy fibers and Purkinje cell spines appearing in the granular layer and central mass $[176,183]$. Despite this, intracellular recordings showed that Reeler Purkinje cells have normal sodium- and calcium-dependent spikes [184]. The homozygous Reeler inferior olivary complex is reduced in size by $22.6 \%$ [127].

During brain development, the upward migration of young neurons is terminated in the depths of the neocortex; additionally, abnormally extensive contacts between glial fibers and somata of post-migratory cells appear to be sustained in Reeler mutants suggesting that abnormal adhesions between post-migratory cells and radial glial fibers obstruct neuronal migration [185]. Within the cerebellum, the role of dysgenesis of radial glia in obstructed migration of Purkinje cells has been shown by Yuasa et al. [186]. Goffinet et al. [179] suggested that the primary defect in the Reeler cerebellum is malposition of Purkinje cells and that the mutation affects the terminal phase of migration of these cells in the cerebellum. However, findings of normal cerebellums in normal mouse-Reeler chimera suggest that the disturbance of neuronal migration in Reelers is attributable to abnormal cell-to-cell interactions between young neurons and the radial glia [187] and is not determined cellautonomously [188].

Reeler mice have lower neurogenesis rates and increased susceptibility to ischemic brain injury [189] and to epileptic seizures [190]. In humans, autosomal recessive lissencephaly is associated with mutations in the reelin encoding gene; and as with Reeler mice, neuronal migration is impaired and abnormalities in the cerebellum develop [191].

Reeler mice have an interesting behavioral phenotype. Homozygous Reeler mice performed poorly on the active avoidance task and on the radial arm maze task; however, they were able to improve to a level similar to wild-type controls after training [117]. Reeler mice also performed poorly on the spontaneous alternation task in the T-maze, water maze, stationary beam, coat-hanger and rotarod tests [192].

Various behavioral abnormalities have also been reported in heterozygous Reeler mice. Heterozygous Reeler mice have a deficit in learning olfactory discrimination [193]. Young heterozygous Reeler mice showed significantly lower levels of anxiety- and risk-assessmentrelated behaviors in the elevated plus-maze, whereas adult mice exhibited elevated levels of motor impulsivity and altered pain threshold [194]. Heterozygous mice also exhibited complex changes in startle reactivity and sensorimotor gating [195]. The vocal repertoire of neonatal Reeler mice is characterized by preferential use of a specific two-component call [196]. In heterozygous mice the number of calls is increased and the ontogenetic peak in the frequency of calls is delayed compared to wild type mice, while in homozygous Reeler mice the peak is absent [196]. On the other hand, a detailed behavioral study by Podhorna and Didriksen [197] did not find any differences between heterozygous Reelers and wild type mice. Qiu et al. [198] also reported similar performance in heterozygous Reelers and wild type mice, but found a reduction in contextual-fear-conditionedlearning and impaired hippocampal long-term potentiation in heterozygotes.

Some neurobehavioral abnormalities reported in Reeler mice are thought to parallel some features found in human psychiatric disorders and heterozygous Reeler mice have even been suggested as a model of schizophrenia $[199,200]$. On the other hand, Krueger et al. [201] do not consider heterozygous Reeler mice to be an appropriate model for schizophrenia but rather of general learning deficits associated with many psychiatric disorders.

Several experimental therapies have been developed for heterozygous Reeler mice. Cysteamine treatment was found to improve prepulse inhibition and Y-maze performance [202]. Nicotine treatment elevated reelin in the brain to wild type levels and normalized hyperactivity [203]. Reelin supplementation was also found to enhance associative learning ability and prepulse inhibition [204].

\section{Scrambler mouse}

The spontaneous autosomal recessive scrambler mutation $\left(D a b 1^{s c m-3 J}\right)$ in the disabled-1 (DAB1) gene on chromosome 4 was described by Sweet et al. [205]. The cerebellum of one month old homozygous Scrambler mice is hypoplastic and devoid of folia [205]. Granule cells numbers are reduced by $80 \%$, Purkinje cells numbers are also reduced and only 5\% are normally located [206]. Despite Purkinje cell ectopia, topographic afferents remain conserved [207].

Homozygous Scrambler mice suffer from an unstable ataxic gait and whole body tremor [205] that distinguishes them from controls by as early as P8 [208]. Scrambler mice performed poorly on the rotarod, stationary beam and coat-hanger tests [209], but were able to improve their performance on the vertical grid [210] and were more active in the open field [209]. In the alternation test, Scrambler mice did not alternate above chance levels and they were impaired in both the hidden and visible platform Morris water maze tasks [211].

The Scrambler phenotype is similar to Reeler mice $[205,212]$ despite normal levels of reelin in Scrambler mice [206]. This is because function of extracellular reelin, which is affected in Reeler mice depends on the intracellular protein disabled-1 [206,213]. 


\section{Mouse models of human hereditary cerebellar ataxias, genetically engineered and new cerebellar mutants}

New sources of cerebellar mutant mice include transgene technology, induced and targeted mutations and mutagenesis enhanced with mutagen substances $[214,215]$. The latter approach is capable of providing large numbers of random mutations carriers that can be identified according to the abnormal phenotype. Many mouse models of cerebellar disorders, namely those genetically engineered, are related to particular human disease.

\section{SCA1}

Spinocerebellar ataxia type 1 (SCA1) is one of the autosomal dominant hereditary ataxias. It is caused by an enlarged region of CAG trinucleotides repeat in the ataxin-1 gene which results in a poly-glutamine tract (polyQ) expansion in the ataxin-1 protein. Normal length varies between 6 and 35 repeats, while in SCA1 patients it is $39-83$ (for review see [216]).

Burright et al. [217] generated transgenic SCA1 mice carrying the allele with 82 CAG repeats under the control of the murine Pcp2 promoter, which is supposed to be capable of directing transgene expression specifically to Purkinje cells. Five lines of the mice showed transgene expression levels 10-100-fold greater than levels of endogenous mouse ataxin-1 mRNA [217]. Morphologic changes had varying intensities depending on the transgenic mouse line and on the presence of heterozygous or homozygous combinations of the transgene [217]. Morphologic changes consisted of a marked loss of Purkinje cells, abnormal Purkinje cell dendritic trees, Bergmann glia proliferation, shrinkage and gliosis of the molecular layer and the presence of ectopic Purkinje cells in the molecular and granular layers [217]. Progressive ataxia appeared earliest (at the age of 12 weeks) in the line with the highest transgene expression; however, among other lines ataxia onset and severity were not strictly correlated with transgene mRNA [217]. Clark et al. [218] described the same SCA1 mice shorter strides at 12 weeks and dramatic gait pattern abnormalities at 1 year, and diminished performance on the rotarod test obvious by 5 weeks.

Transgenic mice helped in the discovery of some possible components of the pathogenesis of SCA1. Klement et al. [219] demonstrated that while nuclear localisation of pathological ataxin- 1 is necessary, its nuclear aggregation is not required to initiate pathogenesis in transgenic mice. Cummings et al. [220] suggested that impaired proteasomal degradation of mutant ataxin-1 may contribute to SCA1 pathogenesis in transgenic mice. Expanded ataxin-1 has been found to mediate downregulation of genes involved in signal transduction and calcium homeostasis in SCA1 mice prior to manifestation of the pathology [221].

\section{SCA2}

Transgenic mice carrying the human ataxin-2 gene, with an enlarged CAG repeat sequence, are used as a model of human spinocerebellar ataxia type 2 (SCA2). Normal ataxin-2 usually contains 22 or 23 glutamines. SCA2 patients have 32-77 repeats (for review see [216]). SCA2 transgenic mice were generated in several lines with different lengths of the CAG repeat segment and varying in severity of disease manifestation.

Transgenic SCA2 mice with 58 CAG repetitions in the ataxin-2 gene (Q58) under control of the Pcp2 promoter were generated in 3 founder lines (Q58-5B, Q58-11, Q58-19) on the B6D2 hybrid background by Huynh et al. [222]. Purkinje cell numbers were reduced by about $50 \%$ in mice $24-27$ weeks old. Mice from the Q58-19 line showed altered stride length by the 8 weeks and by 16 weeks stride length was reduced in all 3 lines [222]. At 6 weeks, transgenic mice did not differ on the rotarod test from wild type controls, homozygous and heterozygous mice from the Q58-11 line were performing poorly by 16 or 26 weeks respectively. Mice from the Q58-5B line had performances similar to those from the Q58-11 line [222].

Aguiar et al. [223] described a similar pathology in mice (B6D2 hybrid background) carrying the SCA2 transgene with 75 CAG repeats (Q75) under SCA2 selfpromoter regulation, including earlier onset of symptoms in homozygous compared to heterozygous individuals. Dispersion of ataxic symptom onset time was higher in heterozygotes [223].

Transgenic SCA2 mice (B6D2 hybrid background) expressing Q127 ataxin-2 under control of Pcp2 promoter have been shown to have a reduction in the expression of genes specific for Purkinje cells (such as Calb1, Pcp2, Grid2), to have a decrease in Purkinje cell firing frequency first at 6 weeks and progressive motor performance deterioration identified, using an accelerating rotarod test, began at 8 weeks [224]. Motor decline, electrophysiological abnormalities as well as gene expression changes preceded the decrease in Purkinje cell number, which occurred several weeks later [224].

It seems, that the manifestation was more sever in mouse lines with longer polyQ tracts and this phenomenon is in agreement with the inverse correlation observed between CAG repeat length and the age of onset in human patients [225]. Moreover, experiments with transgenic SCA2 mice clearly show that the homozygous combination of the pathologic allele, which is unusual in humans, leads to an earlier onset of symptoms.

Studies on transgenic SCA2 mice have provided important information about certain aspects regarding the pathogenesis of the disease. Huynh et al. [222] showed that nuclear localization and inclusion body formation of ataxin-2 are not necessary for disease development. 
Liu et al. [226] demonstrated that (1) glutamate induced more pronounced cell death in the Q58 Purkinje cell culture than in wild type cells, (2) glutamate-induced cell death was attenuated by dantrolene, a calcium ion stabilizer, and (3) long-term treatment of SCA2-58Q mice with dantrolene alleviated motor deficits and Purkinje cell loss. These findings suggested that disturbed calcium signaling may play a role in the pathogenesis of SCA2 [226].

\section{SCA3}

Spinocerebellar ataxia type 3 (SCA3) is also known as Machado-Joseph disease. It is a late-onset degenerative disease caused by a CAG repeat expansion in the gene encoding the ataxin-3 protein. Within normal alleles, repeat length varies between 12 and 44 CAG trinucleotides. In SCA3 patients, the length is $52-86$ (for review see [216]).

Transgenic mice with alleles containing polyglutamine tracts of 64, 67, 72, 76 and 84 repeats have been generated by Cemal et al. [227]. These transgenic mice suffer from a loss of neurons in the pontine nuclei, increased numbers of reactive astrocytes in the dentate nucleus, cerebellar white matter and moderate degeneration of Purkinje cells, which showed dependence on the transgene copy number [227]. The mice had a wide gait during grid climbing, lowered pelvises, tremor, lower activity, clasping, and slow weight gain [227]. They also had features suggesting peripheral neuropathy characterized by demyelination and degeneration of the dorsal root ganglia [227].

Transgenic mice expressing ataxin-3 with an expanded polyglutamine tract with 79 repeats suffer from progressive ataxia with onset at 5-6 months, followed by progression, despite no prominent neuronal loss in the cerebellum, even as late as 10-11 months [228]. This suggests that neuronal dysfunction and down-regulation of cerebellar expressions of proteins involved in synaptic transmission, signal transduction or regulation of neuronal survival and differentiation, rather than Purkinje cell loss, could be responsible for the decline in cerebellar function [228,229]. Studies on the SCA3 transgenic mouse model have suggested that Purkinje neuron dysfunction associated with altered voltage-activated potassium channels [230], calcium-dependent calpain-type proteases [231], and disruption of dendritic development and metabotropic glutamate receptor signaling in Purkinje cells by mutant ataxin-3 [232] may also play role in the pathogenesis of SCA3. Soluble extended ataxin-3 has shown a tendency for decrease during disease progression in the cerebellum and to inversely correlate with aggregate formation and phenotypic aggravation in SCA3 mice [233].

Boy et al. [234] and Nobrega et al. [235] showed, that symptoms can be alleviated with pathological ataxin-3 expression silencing in diseased transgenic SCA3 mice. Halting the expression of ataxin-3 is seen as a hopeful therapeutic approach since the technique cleared nuclear accumulation of the abnormal protein in SCA3 mice [236]. Stimulation of proteasome activity by Rho-kinase alleviated the neurological phenotype in SCA3 mice since it may promote mutant ataxin-3 degradation [237].

\section{SCA6}

Spinocerebellar ataxia type 6 (SCA6) is due to a CAG repeat expansion in the CACNA1A gene encoding the alpha 1A-voltage-dependent calcium channel (CaV2.1) [238]. Normal alleles have 4-16 repeats, while alleles causing disease contain 20-33 repeats (for review see [216]). Different mutations in the same locus appear in ataxic mouse mutants Tottering [239,240], Leaner [241] and Rocker [242].

Mice expressing CaV2.1, with the 84 polyglutamine tract, developed progressive motor impairment and aggregation of the mutant protein [243]. Homozygous mice exhibited hypoactivity at 17 months and poor performances on the accelerating rotarod [243]. Heterozygotes were indistinguishable from wild type controls based on visual inspection up to 20 months, however, at 19 months they were underperforming on rotarod test [243]. No neuronal loss, no changes in Purkinje cell morphology and no alterations in calbindin immunoreactivity were found in these mice, even as late as 20 months, when motor deficits were already apparent [243].

Studies on SCA6 mice with 28 or 84 polyglutamine repeats have shown that voltage dependence of activation and inactivation, and current density measured in Purkinje cells were not influenced by the polyglutamine tract length, which suggests that alteration of CaV2.1 channel properties does not play a role and that the pathogenesis of SCA6 may be linked to accumulation of mutant channels [243,244]. The decreased whole cell current density could be attributed to a decrease in CaV2.1 channel numbers [243]. In Tottering mice, a mutation in the CACNA1A gene leads to irregular simple spike activities in Purkinje cells without any change in other activity parameters and this abnormality has been suggested as being sufficient to produce behavioral abnormalities [245].

\section{SCA7}

Spinocerebellar ataxia type 7 (SCA7) is a neurodegenerative disease caused by expansion of a CAG repeat within the gene encoding ataxin-7. The normal range is $7-19$ repeats. Pathological alleles contain from 37 to more than 400 CAG triplets. Among SCAs, it is the only one characterized by severe ataxia and at the same time by visual loss due to pigmentary macular degeneration (for review see [216]). 
Nuclear inclusions of mutant ataxin-7, motor coordination and vision impairment have been reported in mice overexpressing full-length mutant ataxin-7 with 90 glutamines (Q90) in Purkinje cells and photoreceptors [246]. Yoo et al. [247] generated an authentic mouse model of SCA7 by targeted insertion of 266 CAG repeats into the mouse SCA7 locus. The mice displayed an infantile form of SCA7 that is manifested by ataxia, visual deficit, impaired short-term synaptic potentiation and premature death [247]. In transgenic mice, expression of the Q92 ataxin-7 in all CNS neurons, except for Purkinje cells, led to severe Purkinje cell degeneration, development of gait ataxia, and formation of truncated ataxin-7 nuclear aggregates that correlated with disease phenotype onset and even to premature death [248]. These findings suggest that the degeneration of Purkinje cells is non-cell-autonomous in SCA7 and that lack of proteolytic cleavage may be one of the SCA7 pathogenetic mechanisms [248]. The next feature of SCA7 pathogenesis may be changes in gene expression. Mice expressing Q52 ataxin-7 and exhibiting motor dysfunction since the age of 7 months had down-regulated mRNA expression of proteins involved in glutamatergic transmission, signal transduction, myelin formation, axon transport, deubiquitination, neuronal differentiation and glial function [249]. Contrary to mice expressing Q92 ataxin-7, mice expressing Q52 did not lose significant numbers of Purkinje cells, despite ataxic symptoms [249].

Experimental therapeutic approaches have been successfully tested in SCA7 transgenic mice. Suppression of mutant gene expression by $50 \%$, started one month after the ataxia onset, was effective at halting or reversing motor symptoms, reducing mutant ataxin-7 aggregation in Purkinje cells and preventing synaptic loss between climbing fibers and Purkinje cells [250]. As with SCA3 mice, augmenting proteasome activity promoted mutant ataxin-7 degradation [237]. It has also been shown that interferon beta was able to induce clearance of ataxin-7 and improved motor function in Q266 SCA7 mice [251].

\section{SCA23}

SCA23 is a rare disease caused by mutations in the gene encoding prodynorphin (for review see [216]). Prodynorphin knock-out mice are more sensitive to noxious stimuli but have normal responses to non-noxious stimuli [252]; additionally, mutant dynorphin proteins have enhanced non-opioid excitatory activities which may underlie development of SCA23 [253]. Nevertheless, these mice have not been tested yet for phenotypic similarity to human SCA23.

\section{DRPLA}

Dentatorubral-pallidoluysian atrophy (DRPLA) is an autosomal dominant neurologic disorder. It manifests as variable combinations of cerebellar ataxia, dementia, epilepsy and choreoathetosis. It is caused by an unstable expansion of CAG repeat in the gene encoding atrophin-1 on chromosome 12 [254]. The age at symptom onset is highly variable and correlates with the length of the polyglutamine tract [254].

Transgenic mice with 78 CAG repeats in the DRPLA gene showed intergenerational instability of the CAG repeat tract, which is typical for human DRPLA [255]. Mice with 76 CAG triplets also revealed instability but no obvious neurological abnormalities [256,257]. Mice having 129 repeats revealed a marked neurological phenotype, age dependent dysfunction of the globus pallidus and cerebellum, shrinkage of the distal dendrites of Purkinje cells, intranuclear accumulation of mutant protein and progressive brain atrophy, but no neuronal loss $[256,257]$. Changes in gene expression in the cerebellum and cerebrum, due to intranuclear accumulation of mutant DRPLA protein have been shown [258]. Increase in the severity of motor deficits that parallels the length of the expanded CAG repeats and with age, has been observed in mice carrying full-length mutant human DRPLA gene with 76, 96, 113 or 129 CAG repeats.

\section{Niemann-pick disease model}

Niemann-Pick disease is an autosomal recessive inherited storage disease with types A, B and C. Its manifestation is heterogeneous and consists of extraneural and CNS (in type A and C) affections, with depletion of Purkinje cells being seen in type C. Mutations causing the analogous disease in mice have been described and transgenic mouse models for Niemann-Pick disease type $C$ have been created [259-261]. Poor performances on motor tests and also on the water maze task with the hidden escape platform have been reported in these mice [262,263]. Cerebellar affection, however, is only one of multiple pathologies affecting these mice. Therefore this model is not suitable for studying cerebellar functions. Nevertheless, it has been successfully used several times to investigate the pathogenesis of NiemannPick type C disease [264,265] and to assess pharmacological [266] and transplantation [267-270] methods that could potentially be used to treat those afflicted with Niemann-Pick type $\mathrm{C}$ disease.

\section{Friedreich ataxia}

Friedreich ataxia (FRDA) is a human autosomal recessive disease caused by a GAA triplet repeat expansion in the gene encoding the frataxin, a mitochondrial protein involved in iron metabolism (for review see [271]). Several transgenic mouse models have been generated. Al-Mahdavi et al. [272] reported vacuoles within dorsal root ganglia neurons, axons demyelination, coordination deficits and decreased locomotor activity. The next mouse 
model with a frataxin transgene containing 230 GAA repeats and reduced expression of wild type frataxin did not develop motor coordination impairment and iron metabolism anomalies [273]. Several other transgenic mice carrying pathological frataxin gene alleles have yet to be tested for Friedreich ataxia phenotype.

\section{Robo3-deficient mouse}

Robo3 (known also as Rig-1 or HGPPS), a member of the roundabout family of transmembrane receptors, has been shown to be important for neurons and axons to cross the midline in mice [274,275]. Robo proteins also regulate midline crossing of precerebellar neurons and cerebellofugal axons [275-277]. In humans, Robo3 is related to a syndrome involving horizontal gaze palsy with progressive scoliosis (HGPPS) [278,279]. Robo3 deficient mice are not a model of cerebellar degeneration but rather a developmental disorder of the laterality of projections from axons including those connecting the cerebellum with other CNS structures. Renier et al. [280] generated Ptf1a::cre;Robo3 ${ }^{\text {lox/lox }}$ mice lacking the interolivary commissure. While in normal mice inferior olive neurons project contralaterally to the cerebellum, in Ptf1a::cre;Robo $3^{\text {lox/lox }}$ mice $67 \%$ of inferior olive neurons have ipsilateral projections [280]. For the flocculus of Ptf1a::cre;Robo $3^{\text {lox/lox }}$ mice, $76 \%$ of olivary neurons providing climbing fibers were located ipsilaterally [281]. On the other hand, lateralization of mossy fiber projections into the cerebellum and the size, structure and cytoarchitecture of the cerebellum were not affected [280,281]. Nevertheless, these mice suffer from severe ataxia starting around postnatal day 10 and the motor deficit has been shown to be even more severe than that seen in Lurcher mice, which completely lack cerebellar cortex output [280]. Ptf1a::cre;Robo $3^{\text {lox/lox }}$ mice showed deficits in the gain and phase of the optokinetic reflex and vestibulo-ocular reflex in light and higher variability of both reflexes compared with control mice [281].

\section{Research applications for mutant ataxic mice Functional abnormalities}

Cerebellar mutant mice suffer from more or less severe cerebellar ataxia but also display a wide range of interesting and variable cognitive impairments and behavioral abnormalities. Therefore cerebellar mutants could provide information about the involvement of the cerebellum in cognitive, affective and executive processes.

Experiments in cerebellar mutant mice have confirmed the role of the cerebellum in motor learning (for review see [282]). Nevertheless, motor learning deficits are not equal in all cerebellar mutants. E.g. as shown by Lalonde et al. [31], Staggerer mice did not improve their motor performance during repeated training, while Lurcher and hot-foot mice did. Eyelid conditioning seems to be a good model of associative learning that enables analysis of the execution of a learned motor response. Using this technique, changes in classical conditioning, in execution of the conditioned response and the modulating role of interpositus and red nuclei were described in Lurcher mice [42,46,283]. Pcd mice have also been shown to be partially defective in eyelid conditioning and residual learning ability has been attributed to the deep cerebellar nuclei [83,284]. Classical eye blink conditioning deficit has also been found in global and Purkinje cell-specific Fmr1 gene knockout mice which show morphological and behavioral features similar to fragile X syndrome patients [285]. Defects of conditioned eye blink responses have also been found in human cerebellar patients [286,287].

Spatial learning or orientation deficits in various types of mazes have been reported in many types of cerebella mutants: Lurcher [41-44], Hot-foot [62], Pcd [81], Nervous [94], Staggerer [117], Weaver [144], Reeler [192], Scrambler [211] and in Niemann-Pick C disease mouse model [262,263]; however, difficulties in solving water maze tasks are not uniform (compare references e.g. [44,81] and [94]). While impaired navigation to a hidden goal with preserved ability to navigate toward a visible goal (pcd, Nervous) is supposed to indicate a spatial learning defect, impaired navigation to both hidden and visible goals (Lurcher) suggests more complex problems [44]. Furthermore, it is not always clear whether the poor performance in the maze is specifically a consequence of impaired spatial learning ability since motor and oculomotor deficits or affective function abnormalities could influence the behavior of the mice in the maze.

Some behavioral abnormalities of cerebellar mutants resemble features of human psychiatric disorders. Conversely, abnormalities in cerebellar morphology have been described e.g. in autistic patients [288-290]. Cerebellar pathology is considered to play a key role in the pathogenesis of autistic spectrum disorders (for review see [291]). Autism spectrum disorders have often been shown to be accompanied by developmental Purkinje cell loss (e.g. [292]) and some patient features are analogous to behavioral and cognitive abnormalities in cerebellar mutant mice [53,293]. Heterozygous Reeler mice have been proposed, with some objections, as model of schizophrenia or neurodevelopmental psychiatric diseases in general [199-201,294]. Lurcher mice with their behavioral disinhibition and stress axis hyper-reactivity also mimic some psychiatric abnormalities [42,49-52].

It is, however, impossible to consider common cerebellar mutant mice to be direct models of psychiatric disorders. For psychiatric disorders involving a cerebellar pathology, there are more specific models, such as Fmr1 gene knockout mice for fragile $\mathrm{X}$ syndrome [285] or neuroligin-3 knockout mice, a model for nonsyndromic 
autism [295]. Nevertheless, detailed analysis of behavioral abnormalities and their correlation with structural, ultrastructural or biochemical changes in the cerebellum of various types of ataxic mutant mice could reveal the role of the cerebellum in control of behavior and the impact of cerebellar defects in behavioral pathology.

On the cell function level, firing patterns of Purkinje cells tuned by the activity of other cerebellar components and cerebellar inputs is crucial for cerebellar functions (for review see [296]). Many mutations lead to a change in spatiotemporal firing patterns and motor and cognitive impairments [296], e.g. CACNA1A gene mutation in Tottering mice [245], Grik mutation in Weaver mice [137], mice selectively lacking large-conductance voltage- and calcium-activated potassium channels in the Purkinje cells [297], mice deficient in calretinin [298], etc. In calretinin deficient mice, motor coordination was restored with selective re-expression of calretinin in granule cells [299]. Some mutations led specifically to impairment of plasticity of certain cerebellar neuronal types and their synapses with impact on motor learning (for review see [300]).

\section{Neurotransplantation research in cerebellar mutant mice}

Cerebellar mutant mice are used as investigative models of neurotransplantation therapy for cerebellar degeneration. Pcd and Lurcher mice have been the most frequently used. Recently, however, transgenic mouse models of human diseases have been viewed with increasing interest. Neurotransplantation research not only helps in the search for therapeutic strategies, but also offers deeper understanding of the role of neurogenic (either positive or negative) signals from normal and injured cerebellar tissue. Generally, cerebellar tissue is considered to have low neurogenic capacity.

Pcd mice have been shown to be a good model for neurotransplantation research. Donor Purkinje cells were able to leave solid embryonic cerebellar grafts, migrate to their final position in the molecular layer [301] and become integrated synaptically within the pcd cerebellar cortex [302,303]. Sotelo and Alvarado-Mallart [301] suggested that the deficient pcd molecular layer exerts a selective neurotropic effect on neurons of the missing category. Reestablishment of corticonuclear projections has also been demonstrated in pcd mice [304-306]. Nevertheless, proximity of the grafted Purkinje cells to the deep cerebellar nuclei is necessary [306] since the granular layer acts as a barrier that prevents nerve fibers sprouting toward the deep cerebellar nuclei [307]. Carletti and Rossi [308] found, that the pcd cerebellum provides signals inducing selective mechanisms that favor the survival of donor Purkinje cells. Bilateral transplantation of a fetal cerebellar cell suspension into the deep cerebellar nuclei led to an improvement of motor performance in pcd mice [309,310].
Lurcher mice have also been used to study transplantation of embryonic cerebellar cells. Aggregates of grafted cells with organotypic organization on the surface of the host cerebellum and invasion of grafted cells into the host's molecular layer have been observed [311-313]. Solid embryonic cerebellar grafts survived well for 6 months in both Lurcher and wild type mice but lacked sufficient interactions with the host cerebellum [314]. Timely transplantation of normal embryonic Purkinje cells can prevent degeneration of cerebellar granule cells and inferior olive neurons and this provides evidence for secondary nature of degeneration in these cell categories [312]. A significant improvement in performance on motor tests was observed by Jones et al. [315] after transplantation of mesenchymal stem cells into the cerebellum of newborn Lurcher mice. Donor cells were located adjacent to the Purkinje cell layer and produced neurotrophic factors (BDNF, NT-3 and GDNF) that increased Purkinje cell survival [315].

In newborn nervous mice, intracerebellar transplantation of undifferentiated neural stem cells supported mitochondrial function, rescued Purkinje cells and improved motor coordination [316]. Neural stem cells almost normalized previously elevated levels of tissue plasminogen activator, in the cerebellum, and thereby modulated the pathway associated with Purkinje cell degeneration [316]. In Weaver mice, cerebellar grafts developed a trilaminar organization, grafted granule-like cells proliferated and were able to make synaptic contacts [317].

In SCA1 mice, transplantation of an embryonic cerebellar cell suspension led to improvement in motor function [318]. Transplantation of neural precursor cells improved motor skills, enhanced survival of Purkinje cells and normalized Purkinje cell membrane potentials in SCA1 mice; all this despite none of the grafted cells being able to adopt Purkinje cell-like characteristics [319]. Furthermore, intrathecal injection of mesenchymal stem cells mitigated cerebellar disorganization, suppressed atrophy of Purkinje cell dendrites and normalized deficits in motor coordination in SCA1 mice [320]. In SCA2 transgenic mice, Chang et al. [321] found that intravenous injection of human mesenchymal stem cells increased the survival of host Purkinje cells, delayed onset of disease and improved motor function.

In the mouse model of Niemann-Pick disease type C, mesenchymal stem cells were successfully grafted. Bone marrow-derived mesenchymal stem cell transplantation reduced astrocytic and microglial activation in the cerebellum [267], led to an increase in Purkinje cell numbers and motor skill improvement and it has been shown that electrically active Purkinje neurons originated from existing Purkinje cells through fusion-like events with grafted mesenchymal stem cells [268]. Also transplantation of adipose tissue-derived stem cells rescued Purkinje neurons, alleviated inflammatory responses 
and restored motor coordination in Niemann-Pick disease type C mice [269].

The first clinical trials have already tested neurotransplantation therapy in human patients with cerebellar degeneration $[322,323]$. The results seem to be promising, but cerebellar transplantation is not routine therapy, yet, and intensive preclinical research is still necessary. With regard to the variability in the nature of human hereditary cerebellar ataxias, different approaches for individual diseases will be probably necessary.

\section{Conclusion}

Studies on cerebellar mutant mice have provided a lot of information about cerebellar function, manifestation of cerebellar disorders, and pathogenesis and therapy of cerebellar degeneration. Since Purkinje cell axons are the sole output of the cerebellar cortex, mice with complete loss of the Purkinje cells (e.g. Lurcher, pcd) represent models of functional cerebellar decortication.

Studies of cerebellar degeneration in mutant mice have revealed the mechanisms of cell death, which have been found to be necrosis, apoptosis, or autophagy and it has been even suggested that cell death may involve combinations of multiple pathways [14,23]. Although the degeneration affects the vast majority of Purkinje cells, in certain of the cerebellar mutants, a few Purkinje cells often survive until late adulthood. The distribution of these cells, as well as the irregular progress of degeneration within the cerebellar cortex often follows characteristic patterns that vary from one mutant strain to the next. This variable Purkinje cells sensitivity to the effects of the mutations shows their heterogeneity [324]. Cerebellar mutant mice are also a model of secondary cell degeneration caused by deprivation of postsynaptic targets or synaptic inputs.

Cerebellar mutants are variable relative to the extent of degeneration of individual cerebellar and extra-cerebellar cell types, and cell death pathways. For example, Lurcher, Purkinje cell degeneration and Nervous mice suffer from severe Purkinje cell loss. In Staggerer or Weaver mutants, the main problem is depletion of granule cells. Poor innervation of Purkinje cells is the dominant pathology in Hotfoot mice, whereas in Reeler, Scrambler and Weaver mice, defective neuronal migration is responsible for cerebellar disorganization.

Though, the basic manifestation of cerebellar dysfunction is similar in most of the mouse models of cerebellar degenerations, some particular signs differ. Moreover, some of the mutations have extra-cerebellar impacts, which are integral components of the phenotype (e.g. olfactory bulb, retina and thalamus degeneration in pcd mice, dorsal cochlear nuclei of Nervous mice, complex CNS disorganization in Weaver and Reeler mice - see above). Such variability and complexity of manifestations in ataxic mutant mouse models is advantageous regarding the complexity of symptoms of human cerebellar degenerations. They provide tools to search for factors determining particular phenotypic features and relationships between morphologic and functional abnormalities. Knowledge of the factors modifying the course of the disease is important for understanding its pathogenesis as well as for selection of optimal therapeutic approaches. On the other hand, interpretation of examinations of particular neural functions in cerebellar mutant mice is difficult and ambiguous since the performance on tests can be influenced by multiple factors such as motor abilities, cognitive functions, anxiety or motivation.

It should be taken into account, however, that mouse models of hereditary cerebellar degenerations have serious limitations that prevent direct translation of findings to humans. There are, of course, species differences in anatomy, metabolism, behavior, etc. between mice and men. Spontaneous mouse mutations are usually not identical to human ones and therefore mouse diseases can only be similar to human diseases. On the other hand, transgenic mice carry human pathological alleles and thus they can be used as models for specific human diseases. Nevertheless, even in transgenic mice the action of the mutation could significantly differ from the natural human mutation. The transgene could be under control of different promoters and its expression could differ from that seen in humans regarding intensity and cell type. The transgene usually does not replace the mouse wild type allele, if not knocked-out. In these cases the mouse has both pathological as well as fully expressed normal gene products. Autosomal dominant ataxias appear in humans mostly in the form of heterozygotes. However, mice can also be studied as homozygous individuals. These experiments have shown that homozygous mice often display more severe pathological phenotype than heterozygous mice suggesting that the diseases might be more accurately described as having a semi-dominant nature. Finally, cerebellar mutant mice have the phenotypic traits of the original strain, which could also interfere with the manifestation of the mutation of interest. Therefore it is not easy to compare two cerebellar mutants when they are derived from different mouse strains. Some mutants are available in more strains of origin and some caution in necessary when comparing findings of studies that have used different strains of the same mutant. Most transgenic mice are created using F1 hybrid strains which are not stable across subsequent generations. Despite the limitations, cerebellar mutant mice are invaluable tools for research, when the goal is a better understanding the pathogenesis of cerebellar degenerative disorders and, hopefully, finding effective therapies for humans.

Cerebellar mutant mice will continue to serve as valuable tools in preclinical studies investigating therapeutic 
methods for treating human cerebellar degenerations. Nevertheless, deep phenotypic characterization, especially of the new transgenic mouse models, and elucidation of the pathogenesis and relationship of the functional disorders to the cerebellum will remain important. Verification of the conformity of the mouse models with human diseases on the morphological, functional and molecular level is also crucial for translation of experimental research to human medicine.

\section{Competing interest}

The author declares that they have no competing interest.

\section{Acknowledgment}

The article was supported by the Charles University Research Fund (project number P36), the Faculty of Medicine in Pilsen, by project CZ.1.05/2.1.00/ 03.0076 from the European Regional Development Fund and by projects COST No. LD12057 and 12056 of the Ministry of Education, Youth and Sport of the Czech Republic. The author would like to thank to Thomas Secrest for language editing.

Received: 28 February 2014 Accepted: 21 April 2014

Published: 16 June 2014

\section{References}

1. Schmahmann JD, Sherman JC: Cerebellar cognitive affective syndrome. Int Rev Neurobiol 1997, 41:433-440.

2. Manto MU: The wide spectrum of spinocerebellar ataxias (SCAs). Cerebellum 2005, 4:2-6

3. Manto M, Marmolino D: Animal models of human cerebellar ataxias: a cornerstone for the therapies of the twenty-first century. Cerebellum 2009, 8:137-154

4. Phillips RJS: "Lurcher", a new gene in linkage group XI of the house mouse. J Genet 1960, 57:35-42.

5. Zuo J, De Jager PL, Takahasi K, Jiang W, Linden DJ, Heintz H: Neurodegeneration in Lurcher mice caused by mutation of $\delta 2$ glutamate receptor gene. Nature 1997, 388:769-773.

6. Araki K, Meguro H, Kushiya E, Takayama C, Inoue Y, Mishina M: Selective expression of the glutamate receptor channel delta 2 subunit in cerebellar Purkinje cells. Biochem Biophys Res Commun 1993, 197:1267-1276.

7. De Jager PL, Zuo J, Cook SA, Heintz N: A new allele of the lurcher gene, lurcher. Mamm Genome 1997, 8:647-650.

8. Cheng SS, Heintz N: Massive loss of mid- and hindbrain neurons during embryonic development of homozygous Lurcher mice. J Neurosci 1997, 17:2400-2407

9. Caddy KWT, Biscoe TJ: Structural and quantitative studies on the normal $\mathrm{C} 3 \mathrm{H}$ and Lurcher mutant mouse. Philos Trans R Soc London Ser B Biol SCi 1979, 287:167-201.

10. Zanjani SH, Selimi F, Vogel MW, Haeberle AM, Boeuf J, Mariani J, Bailly YJ: Survival of interneurons and parallel fiber synapses in a cerebellar cortex deprived of Purkinje cells: studies in the double mutant mouse Grid2 ${ }^{\text {Lc/-; }}$; $\mathrm{Bax}^{-1-}$. J Comp Neurol 2006, 497:622-635.

11. Duffin CA, McFarland R, Sarna JR, Vogel MW, Armstrong CL: Heat shock protein 25 expression and preferential Purkinje cell survival in the lurcher mutant mouse cerebellum. J Comp Neurol 2010, 518:1892-1907.

12. Wetts R, Herrup K: Interaction of granule, Purkinje and inferior olivary neurons in lurcher chimeric mice. I. Qualitative studies. J Embryol Exp Morphol 1982, 68:87-98.

13. Wetts $R$, Herrup K: Interaction of granule, Purkinje and inferior olivary neurons in lurcher chimeric mice. II. Granule cell death. Brain Res 1982, 250:358-362.

14. Nishiyama J, Yuzaki M: Excitotoxicity and autophagy: lurcher may not be a model of "autophagic cell death". Autophagy 2010, 6:568-570.

15. Vogel MW, Fan H, Sydnor J, Guidetti P: Cytochrome oxidase activity is increased in +/Lc Purkinje cells destined to die. Neuroreport 2001, 12:3039-3043.

16. Norman DJ, Feng L, Cheng SS, Gubbay J, Chan E, Heintz N: The lurcher gene induces apoptotic death in cerebellar Purkinje cells. Development 1995, 121:1183-1193.
17. Purkartova Z, Vozeh F: Cerebellar degeneration in Lurcher mice under confocal laser scanning microscope. Microsc Res Tech 2013, 76:545-551.

18. Selimi F, Doughty M, Delhaye-Bouchaud N, Mariani J: Target-related and intrinsic neuronal death in Lurcher mutant mice are both mediated by caspase-3 activation. J Neurosci 2000, 20:992-1000.

19. Dumesnil-Bousez N, Sotelo C: Early development of the Lurcher cerebellum: Purkinje cell alterations and impairment of synaptogenesis. J Neurocytol 1992, 21:506-529.

20. Dusart I, Guenet IL, Sotelo C: Purkinje cell death: differences between developmental cell death and neurodegenerative death in mutant mice. Cerebellum 2006, 5:163-173.

21. Yue Z, Horton A, Bravin M, DeJager PL, Selimi F, Heintz N: A novel protein complex linking the $\delta 2$ glutamate receptor and autophagy: implications for neurodegeneration in Lurcher mice. Neuron 2002, 35:921-933.

22. Wang QJ, Ding Y, Kohtz DS, Mizushima N, Cristea IM, Rout MP, Chait BT, Zhong Y, Heintz MP, Yue Z: Induction of autophagy in axonal dystrophy and degeneration. J Neurosci 2006, 26:8057-8068.

23. Zanjani HS, Lohof AM, McFarland R, Vogel MW, Mariani J: Enhanced survival of wild-type and Lurcher Purkinje cells in vitro following inhibition of conventional PKCs or stress-activated MAP kinase pathways. Cerebellum 2013, 12:377-389.

24. Vogel MW, Sunter K, Herrup K: Numerical matching between granule and Purkinje cells in lurcher chimeric mice: a hypothesis for the trophic rescue of granule cells from target-related cell death. J Neurosci 1989, 9:3454-3462.

25. Heckroth JA: A quantitative morphological analysis of the cerebellar nuclei in normal and lurcher mutant mice. I. Morphology and cell number. J Comp Neurol 1994, 343:173-182.

26. Heckroth JA: A quantitative morphological analysis of the cerebellar nuclei in normal and lurcher mutant mice. II. Volumetric changes in cytological components. J Comp Neurol 1994, 343:182-192.

27. Sultan F, König T, Möck M, Thier P: Quantitative organization of neurotransmitters in the deep cerebellar nuclei of the Lurcher mutant. J Comp Neurol 2002, 452:311-323.

28. Fortier P, Smith AM, Rossignol S: Locomotor deficits in the cerebellar mutant mouse, Lurcher. Exp Brain Res 1987, 66:271-286.

29. Le Marec N, Lalonde R: Treadmill performance of mice with cerebellar lesions: 2. Lurcher mutant mice. Neurobiol Learn Mem 2000, 73:195-206.

30. Lalonde R, Botez MI, Joyal CC, Caumartin M: Motor abnormalities in Lurcher mutant mice. Physiol Behav 1992, 51:523-525.

31. Lalonde R, Filali M, Bensoula AN, Lestienne F: Sensorimotor learning in three cerebellar mutant mice. Neurobiol Learn Mem 1996, 65:113-120

32. Thullier F, Lalonde R, Cousin X, Lestienne F: Neurobehavioral evaluation of lurcher mutant mice during ontogeny. Dev Brain Res 1997, 100:22-28.

33. Le Marec N, Caston J, Lalonde R: Impaired motor skills on static and mobile beams in lurcher mutant mice. Exp Brain Res 1997, 116:131-138.

34. Hilber $P$, Lalonde R, Caston J: An unsteady platform test for measuring static equilibrium in mice. J Neurosci Meth 1999, 88:201-205.

35. Lalonde R, Joyal CC, Guastavino JM, Botez Ml: Hole poking and motor coordination in Lurcher mutant mice. Physiol Behav 1993, 54:41-44.

36. Lalonde $\mathrm{R}$, Bensoula AN, Filali M: Rotorod sensorimotor learning in cerebellar mutant mice. Neurosci Res 1995, 22:423-426.

37. Hilber P, Caston J: Motor skills and motor learning in Lurcher mutant mice during aging. Neuroscience 2001, 102:615-623.

38. Markvartova V, Cendelin J, Vozeh F: Changes of motor abilities during ontogenetic development in Lurcher mutant mice. Neuroscience 2010, 168:646-651.

39. Markvartova V, Cendelin J, Vozeh F: Effect of dimethyl sulfoxide in cerebellar mutant Lurcher mice. Neurosci Lett 2013, 543:142-145.

40. Van Alphen AM, Schepers T, Luo C, De Zeeuw Cl: Motor performance and motor learning in Lurcher mice. Ann N Y Acad Sci 2002, 978:413-424.

41. Lalonde R, Lamarre Y, Smith AM: Does the mutant mouse Lurcher have deficits in spatially oriented behaviours? Brain Res 1988, 455:24-30

42. Porras-Garcia E, Cendelin J, Dominguez-del-Toro E, Vozeh F, Delgado-Garcia JM: Purkinje cell loss affects differentially the execution, acquisition and prepulse inhibition of skeletal and facial motor responses in Lurcher mice. Eur J Neurosci 2005, 21:979-988.

43. Cendelin J, Korelusova I, Vozeh F: The effect of repeated rotarod training on motor skills and spatial learning ability in Lurcher mutant mice. Behav Brain Res 2008, 189:65-74. 
44. Lalonde $\mathrm{R}$, Thifault S: Absence of an association between motor coordination and spatial orientation in lurcher mutant mice. Behav Genet 1994, 24:497-501.

45. Hilber P, Jouen F, Delhaye-Bouchaud N, Mariani J, Caston J: Differential roles of cerebellar cortex and deep cerebellar nuclei in learning and retention of a spatial task: studies in intact and cerebellectomized lurcher mutant mice. Behav Genet 1998, 28:299-308.

46. Porras-Garcia E, Sanchez-Campusano R, Martinez-Vargas D, Dominguez-del-Toro E, Cendelin J, Vozeh F, Delgado-Garcia JM: Behavioral characteristics, associative learning capabilities, and dynamic association mapping in an animal model of cerebellar degeneration. J Neurophysio/ 2010, 104:346-365.

47. Caston J, Chianale C, Delhaye-Bouchaud N, Mariani J: Role of the cerebellum in exploration behavior. Brain Res 1998, 808:232-237.

48. Monnier C, Lalonde R: Elevated +-maze and hole-board exploration in Lurcher mutant mice. Brain Res 1995, 702:169-172.

49. Frederic F, Chautard T, Brochard R, Chianale C, Wollman E, Oliver C, Delhaye-Bouchaud N, Mariani J: Enhanced endocrine response to novel environment stress and endotoxin in Lurcher mutant mice. Neuroendocrinology 1997, 66:341-347

50. Hilber $\mathrm{P}$, Lorivel T, Delarue C, Caston J: Stress and anxious-related behaviors in Lurcher mutant mice. Brain Res 2004, 1003:108-112.

51. Lorivel T, Gras M, Hilber P: Effects of corticosterone synthesis inhibitor metyrapone on anxiety-related behaviors in Lurcher mutant mice. Physiol Behav 2010, 101:309-314.

52. Tuma J, Cendelin J, Vozeh F: Maternal infanticide and low maternal ability in cerebellar mutants Lurcher. Neuro Endocrinol Lett 2013, 34:101-106.

53. Dickson PE, Rogers TD, Del Mar N, Martin LA, Heck D, Blaha CD, Goldowitz D, Mittleman G: Behavioral flexibility in a mouse model of developmental cerebellar Purkinje cell loss. Neurobiol Learn Mem 2010, 94:220-228.

54. McKimm E, Corkill B, Goldowitz D, Albritton LM, Homayouni R, Blaha CD, Mittleman G: Glutamate dysfunction associated with developmental cerebellar damage: relevance to autism spectrum disorders. Cerebellum 2014, DOI 10.1007/s12311-013-0541-4.

55. Lalouette A, Guenet JL, Vriz S: Hotfoot mouse mutations affect the delta 2 glutamate receptor gene and are allelic to lurcher. Genomics 1998, 50:9-13.

56. Lalouette A, Lohof A, Sotelo C, Guenet J, Mariani J: Neurobiological effects of a null mutation depend on genetic context: comparison between two hotfoot alleles of the delta-2 ionotropic glutamate receptor. Neuroscience 2001, 105:443-455

57. Motohashi J, Kakegawa W, Yuzaki M: Ho15J: a new hotfoot allele in a hot spot in the gene encoding the delta2 glutamate receptor. Brain Res 2007, 1140:153-160

58. Matsuda S, Yuzaki M: Mutation in hotfoot- $4 \mathrm{~J}$ mice results in retention of delta2 glutamate receptors in ER. Eur J Neurosci 2002, 16:1507-1516.

59. Guastavino JM, Sotelo C, Damez-Kinselle I: Hot-foot murine mutation: behavioral effects and neuroanatomical alterations. Brain Res 1990, 523:199-210.

60. Liu QA, Shio H: Mitochondrial morphogenesis, dendrite development, and synapse formation in cerebellum require both $\mathrm{Bcl}-\mathrm{w}$ and the glutamate receptor delta2. PLoS Genet 2008, 4:e1000097.

61. Lalonde R, Hayzoun K, Selimi F, Mariani J, Strazielle C: Motor coordination in mice with hotfoot, Lurcher, and double mutations of the Grid2 gene encoding the delta-2 excitatory amino acid receptor. Physiol Behav 2003 80:333-339.

62. Filali M, Lalonde R, Bensoula AN, Guastavino JM, Lestienne F: Spontaneous alternation, motor activity, and spatial learning in hot-foot mutant mice. J Comp Physiol A 1996, 178:101-104.

63. Mullen RJ, Eicher EM, Sidman RL: Purkinje cell degeneration, a new neurological mutation in the mouse. Proc Natl Acad Sci USA 1976, 73:208-212

64. Fernandez-Gonzalez A, La Spada AR, Treadaway J, Higdon JC, Harris BS, Sidman RL, Morgan JI, Zuo J: Purkinje cell degeneration (pcd) phenotypes caused by mutations in the axotomy-induced gene, Nna1. Science 2002, 295:1904-1906.

65. Landis SC, Mullen RJ: The development and degeneration of Purkinje cells in pcd mutant mice. J Comp Neurol 1978, 177:125-143.

66. Baltanas FC, Berciano MT, Valero J, Gomez C, Diaz D, Alonso JR, Lafarga M, Weruaga E: Differential glial activation during the degeneration of Purkinje cells and mitral cells in the PCD mutant mice. Glia 2013, 61:254-272.
67. Kyuhou S, Kato N, Gemba H: Emergence of endoplasmic reticulum stress and activated microglia in Purkinje cell degeneration mice. Neurosci Lett 2006, 396:91-96.

68. Chakrabarti L, Eng J, Ivanov N, Garden GA, La Spada AR: Autophagy activation and enhanced mitophagy characterize the Purkinje cells of pcd mice prior to neuronal death. Mol Brain 2009, 2:24.

69. Berezniuk I, Fricker LD: A defect in cytosolic carboxypeptidase 1 (Nna1) causes autophagy in Purkinje cell degeneration mouse brain. Autophagy 2010, 6:558-559

70. Berezniuk I, Sironi J, Callaway MB, Castro LM, Hirata IY, Ferro ES, Fricker LD: CCP1/Nna1 functions in protein turnover in mouse brain: implications for cell death in Purkinje cell degeneration mice. FASEB J 2010, 24:1813-1823.

71. Rogowski K, van Dijk J, Magiera MM, Bosc C, Deloulme JC, Bosson A, Peris L, Gold ND, Lacroix B, Bosch Grau M, Bec N, Larroque C, Desagher S, Holzer M, Andrieux A, Moutin MJ, Janke C: A family of protein-deglutamylating enzymes associated with neurodegeneration. Cell 2010, 143:564-578.

72. Wu HY, Wang T, Li L, Correia K, Morgan Jl: A structural and functional analysis of Nna1 in Purkinje cell degeneration (pcd) mice. FASEB J 2012, 26:4468-4480.

73. Ghetti B, Norton J, Triarhou LC: Nerve cell atrophy and loss in the inferior olivary complex of "Purkinje cell degeneration" mutant mice. J Comp Neurol 1987, 260:409-422.

74. Triarhou LC: Biological clues on neuronal degeneration based on theoretical fits of decay patterns: towards a mathematical neuropathology. Folia Neuropathol 2010, 48:3-10.

75. Triarhou LC, Norton J, Ghetti B: Anterograde transsynaptic degeneration in the deep cerebellar nuclei of Purkinje cell degeneration (pcd) mutant mice. Exp Brain Res 1987, 66:577-588.

76. O'Gorman S, Sidman RL: Degeneration of thalamic neurons in "Purkinje cell degeneration" mutant mice. I. Distribution of neuron loss. J Comp Neurol 1985, 234:277-297.

77. Blanks JC, Mullen RJ, LaVail MM: Retinal degeneration in the pcd cerebellar mutant mouse. II. Electron microscopic analysis. J Comp Neurol 1982, 212:231-246

78. Blanks JC, Spee C: Retinal degeneration in the pcd/pcd mutant mouse: accumulation of spherules in the interphotoreceptor space. Exp Eye Res 1992, 54:637-644.

79. LaVail MM, Blanks JC, Mullen RJ: Retinal degeneration in the pcd cerebellar mutant mouse. I. Light microscopic and autoradiographic analysis. J Comp Neurol 1982, 212:217-230.

80. Marchena M, Lara J, Aijon J, Germain F, de la Villa P, Velasco A: The retina of the PCD/PCD mouse as a model of photoreceptor degeneration. $A$ structural and functional study. Exp Eye Res 2011, 93:607-617.

81. Goodlett RC, Hamre KM, West JR: Dissociation of spatial navigation and visual guidance in Purkinje cell degeneration (pcd) mutant mice. Behav Brain Res 1992, 47:129-141.

82. Le Marec N, Lalonde R: Sensorimotor learning and retention during equilibrium tests in Purkinje cell degeneration mutant mice. Brain Res 1997, 768:310-316.

83. Chen L, Bao S, Lockard JM, Kim JK, Thompson RF: Impaired classical eyeblink conditioning in cerebellar-lesioned and Purkinje cell degeneration (pcd) mutant mice. J Neurosci 1996, 6:2829-2838.

84. Brown KL, Agelan A, Woodruff-Pak DS: Unimpaired trace classical eyeblink conditioning in Purkinje cell degeneration (pcd) mutant mice. Neurobiol Learn Mem 2010, 93:303-311.

85. Diaz D, Recio JS, Weruaga E, Alonso JR: Mild cerebellar neurodegeneration of aged heterozygous PCD mice increases cell fusion of Purkinje and bone marrow-derived cells. Cell Transplant 2012, 21:1595-1602.

86. Doulazmi M, Hadj-Sahraoui N, Frederic F, Mariani J: Diminishing Purkinje cell populations in the cerebella of aging heterozygous Purkinje cell degeneration but not heterozygous nervous mice. J Neurogenet 2002, 16:111-123.

87. Campbell DB, Hess EJ: Chromosomal localization of the neurological mouse mutations tottering (tg), Purkinje cell degeneration (pcd), and nervous (nr). Brain Res Mol Brain Res 1996, 37:79-84.

88. De Jager PL, Harvey D, Polydorides AD, Zuo J, Heintz N: A high-resolution genetic map of the nervous locus on mouse chromosome 8 . Genomics 1998, 48:346-353.

89. Landis SC: Ultrastructural changes in the mitochondria of cerebellar Purkinje cells of nervous mutant mice. J Cell Biol 1973, 57:782-797. 
90. Li J, Ma Y, Teng YD, Zheng K, Vartanian TK, Snyder EY, Sidman RL: Purkinje neuron degeneration in nervous (nr) mutant mice is mediated by a metabolic pathway involving excess tissue plasminogen activator. Proc Natl Acad Sci USA 2006, 103:7847-7852.

91. Li J, Yu L, Gu X, Ma Y, Pasqualini R, Arap W, Snyder EY, Sidman RL: Tissue plasminogen activator regulates Purkinje neuron development and survival. Proc Natl Acad Sci USA 2013, 110:E2410-E2419.

92. Zanjani $\mathrm{H}$, Herrup K, Mariani J: Cell number in the inferior olive of nervous and leaner mutant mice. J Neurogenet 2004, 18:327-339.

93. Berrebi AS, Mugnaini E: Effects of the murine mutation 'nervous' on neurons in cerebellum and dorsal cochlear nucleus. J Neurocytol 1988, 17:465-484.

94. Lalonde R, Strazielle C: Motor coordination, exploration, and spatial learning in a natural mouse mutation (nervous) with Purkinje cell degeneration. Behav Genet 2003, 33:59-66.

95. Mullen RJ, LaVail M: Two types of retinal degeneration in cerebellar mutant mice. Nature 1975, 258:528-530.

96. LaVail MM, White MP, Gorrin GM, Yasumura D, Porrello KV, Mullen RJ: Retinal degeneration in the nervous mutant mouse. I. Light microscopic cytopathology and changes in the interphotoreceptor matrix. J Comp Neurol 1993, 333:168-181.

97. Hamilton BA, Frankel WN, Kerrebrock AW, Hawkins TL, FitzHugh W, Kusumi K, Russell LB, Mueller KL, van Berkel V, Birren BW, Kruglyak L, Lander ES: Disruption of the nuclear hormone receptor RORalpha in staggerer mice. Nature 1996, 379:736-739.

98. Sidman RL, Lane PW, Dickie MM: Staggerer, a new mutation in the mouse affecting the cerebellum. Science 1962, 137:610-612

99. Hirano A, Dembitzer HM: The fine structure of staggerer cerebellum. J Neuropathol Exp Neurol 1975, 34:1-11.

100. Herrup K, Mullen RJ: Regional variation and absence of large neurons in the cerebellum of the staggerer mouse. Brain Res 1979, 172:1-12.

101. Landis DM, Sidman RL: Electron microscopic analysis of postnatal histogenesis in the cerebellar cortex of staggerer mutant mice. J Comp Neurol 1978, 179:831-863.

102. Herrup K, Mullen RJ: Staggerer chimeras: intrinsic nature of Purkinje cell defects and implications for normal cerebellar development. Brain Res 1979, 178:443-457.

103. Nakagawa $S$, Watanabe $M$, Isobe $T$, Kondo $H$, Inoue $Y$ : Cytological compartmentalization in the staggerer cerebellum, as revealed by calbindin immunohistochemistry for Purkinje cells. J Comp Neurol 1998, 395:112-120

104. Crepel F, Delhaye-Bouchaud N, Guastavino JM, Sampaio I: Multiple innervation of cerebellar Purkinje cells by climbing fibres in staggerer mutant mouse. Nature 1980, 283:483-484

105. Mariani J, Changeux JP: Multiple innervation of Purkinje cells by climbing fibers in the cerebellum of the adult staggerer mutant mouse. J Neurobiol $1980,11: 41-50$

106. Herrup K, Mullen RJ: Role of the Staggerer gene in determining Purkinje cell number in the cerebellar cortex of mouse chimeras. Brain Res 1981, 227:475-485.

107. Herrup K: Role of staggerer gene in determining cell number in cerebellar cortex. I. Granule cell death is an indirect consequence of staggerer gene action. Brain Res 1983, 313:267-274.

108. Herrup K, Sunter K: Numerical matching during cerebellar development: quantitative analysis of granule cell death in staggerer mouse chimeras. J Neurosci 1987, 7:829-836.

109. Roffler-Tarlov S, Sidman RL: Concentrations of glutamic acid in cerebellar cortex and deep nuclei of normal mice and Weaver, Staggerer and nervous mutants. Brain Res 1978, 142:269-283.

110. Roffler-Tarlov S, Herrup K: Quantitative examination of the deep cerebellar nuclei in the staggerer mutant mouse. Brain Res 1981, 215:49-59.

111. Blatt GJ, Eisenman LM: A qualitative and quantitative light microscopic study of the inferior olivary complex in the adult staggerer mutant mouse. J Neurogenet 1985, 2:51-66.

112. Zanjani HS, Mariani J, Delhaye-Bouchaud N, Herrup K: Neuronal cell loss in heterozygous staggerer mutant mice: a model for genetic contributions to the aging process. Brain Res Dev Brain Res 1992, 67:153-160.

113. Yi SS, Hwang IK, Shin JH, Baek SH, Yoon YS, Seong JK: Neuronal differentiation and developmental characteristics in the dentate gyrus of staggerer mutant mice. BMB Rep 2010, 43:122-126.
114. Frederic F, Chianale C, Oliver C, Mariani J: Enhanced endocrine response to novel environment stress and lack of corticosterone circadian rhythm in staggerer (Rora sg/sg) mutant mice. J Neurosci Res 2006, 83:1525-1532.

115. Lalonde R: Motor abnormalities in staggerer mutant mice. Exp Brain Res 1987, 68:417-420.

116. Caston J, Delhaye-Bouchaud N, Mariani J: Motor behavior of heterozygous staggerer mutant $(+/ \mathrm{sg})$ versus normal $(+/+)$ mice during aging. Behav Brain Res 1995, 72:97-102.

117. Goldowitz D, Koch J: Performance of normal and neurological mutant mice on radial arm maze and active avoidance tasks. Behav Neural Biol 1986, 46:216-226.

118. Lalonde R, Botez MI, Boivin D: Object exploration in staggerer mutant mice. Physiol Behav 1987, 41:115-117

119. Goodall G, Gheusi G: Abnormal patterns of maze patrolling in the mutant mouse staggerer. Behav Neural Biol 1987, 47:307-320.

120. Heuze P, Feron C, Baudoin C: Early behavioral development of mice is affected by staggerer mutation as soon as postnatal day three. Brain Res Dev Brain Res 1997, 101:81-84.

121. Patil N, Cox DR, Bhat D, Faham M, Myers RM, Peterson AS: A potassium channel mutation in weaver mice implicates membrane excitability in granule cell differentiation. Nat Genet 1995, 11:126-129.

122. Hirano A, Dembitzer HM: Cerebellar alterations in the weaver mouse J Cell Biol 1973, 56:478-486.

123. Rakic $P$, Sidman RL: Weaver mutant mouse cerebellum: defective neuronal migration secondary to abnormality of Bergmann glia. Proc Natl Acad Sci USA 1973, 70:240-244.

124. Smeyne RJ, Goldowitz D: Development and death of external granular layer cells in the weaver mouse cerebellum: a quantitative study. J Neurosc 1989, 9:1608-1620

125. Sotelo C: Anatomical, physiological and biochemical studies of the cerebellum from mutant mice. II. Morphological study of cerebellar cortical neurons and circuits in the weaver mouse. Brain Res 1975, 94:19-44.

126. Mariani J: Extent of multiple innervation of Purkinje cells by climbing fibers in the olivocerebellar system of weaver, reeler, and staggerer mutant mice. J Neurobiol 1982, 13:119-126.

127. Blatt GJ, Eisenman LM: A qualitative and quantitative light microscopic study of the inferior olivary complex of normal, reeler, and weaver mutant mice. J Comp Neurol 1985, 232:117-128.

128. Herrup K, Trenkner E: Regional differences in cytoarchitecture of the weaver cerebellum suggest a new model for weaver gene action. Neuroscience 1987, 23:871-885.

129. Maricich SM, Soha J, Trenkner E, Herrup K: Failed cell migration and death of purkinje cells and deep nuclear neurons in the weaver cerebellum. Neurosci 1997, 17:3675-3683.

130. Grover BG, Grusser-Cornehls U: Cerebellar afferents in normal and Weaver mutant mice. Brain Behav Evol 1986, 29:162-175.

131. Blatt GJ, Eisenman LM: The olivocerebellar projection in normal $(+/+)$, heterozygous weaver (wv/+), and homozygous weaver (wv/wv) mutant mice: comparison of terminal pattern and topographic organization. Exp Brain Res 1993, 95:187-201.

132. Ozaki M, Hashikawa T, Ikeda K, Miyakawa Y, Ichikawa T, Ishihara Y, Kumanishi T, Yano R: Degeneration of pontine mossy fibres during cerebellar development in weaver mutant mice. Eur J Neurosci 2002, 16:565-574.

133. Rezai Z, Yoon CH: Abnormal rate of granule cell migration in the cerebellum of "Weaver" mutant mice. Dev Biol 1972, 29:17-26.

134. Goldowitz D, Mullen RJ: Granule cell as a site of gene action in the weaver mouse cerebellum: evidence from heterozygous mutant chimeras. J Neurosci 1982, 2:1474-1485.

135. Smeyne RJ, Goldowitz D: Purkinje cell loss is due to a direct action of the weaver gene in Purkinje cells: evidence from chimeric mice. Brain Res Dev Brain Res 1990, 52:211-218.

136. Hirano A, Dembitzer HM, Yoon CH: Development of Purkinje cell somatic spines in the weaver mouse. Acta Neuropathol 1977, 40:85-90.

137. Siggins GR, Henriksen SJ, Landis SC: Electrophysiology of Purkinje neurons in the weaver mouse: iontophoresis of neurotransmitters and cyclic nucleotides, and stimulation of the nucleus locus coeruleus. Brain Res 1976, 114:53-69.

138. Schmidt MJ, Sawyer BD, Perry KW, Fuller RW, Foreman MM, Ghetti B: Dopamine deficiency in the weaver mutant mouse. J Neurosci 1982, 2:376-380 
139. Triarhou LC, Norton J, Ghetti B: Mesencephalic dopamine cell deficit involves areas A8, A9 and A10 in weaver mutant mice. Exp Brain Res 1988, 70:256-265.

140. Oo TF, Blazeski R, Harrison SM, Henchcliffe C, Mason CA, Roffler-Tarlov SK, Burke RE: Neuron death in the substantia nigra of weaver mouse occurs late in development and is not apoptotic. J Neurosci 1996, 16:6134-6145.

141. Sekiguchi M, Nowakowski RS, Nagato Y, Tanaka O, Guo H, Madoka M, Abe $\mathrm{H}$ : Morphological abnormalities in the hippocampus of the weaver mutant mouse. Brain Res 1995, 696:262-267.

142. Savy C, Martin-Martinelli E, Simon A, Duyckaerts C, Verney C, Adelbrecht C, Raisman-Vozari R, Nguyen-Legros J: Altered development of dopaminergic cells in the retina of weaver mice. J Comp Neurol 1999, 412:656-668.

143. Simon A, Savy C, Martin-Martinelli E, Douhou A, Frederic F, Verney C, Nguyen-Legros J, Raisman-Vozari R: Paradoxical increase of tyrosine hydroxylase-immunoreactive retinopetal fibers in the weaver mouse. Brain Res Dev Brain Res 2000, 121:113-117.

144. Lalonde R, Botez MI: Navigational deficits in weaver mutant mice. Brain Res 1986, 398:175-177.

145. Lalonde R: Acquired immobility response in weaver mutant mice. Exp Neurol 1986, 94:808-811.

146. Lalonde R: Motor abnormalities in weaver mutant mice. Exp Brain Res 1987 65:479-481.

147. Derenne A, Arsenault ML, Austin DP, Weatherly JN: Weaver mutant mice exhibit long-term learning deficits under several measures of instrumental behavior. Physiol Behav 2007, 92:1002-1009.

148. Harrison SM, Roffler-Tarlov SK: Cell death during development of testis and cerebellum in the mutant mouse weaver. Dev Biol 1998 195:174-186.

149. Grusser C, Grusser-Cornehls U: Improvement in motor performance of Weaver mutant mice following lesions of the cerebellum. Behav Brain Res 1998, 97:189-194.

150. Migheli A, Attanasio A, Lee WH, Bayer SA, Ghetti B: Detection of apoptosis in weaver cerebellum by electron microscopic in situ end-labeling of fragmented DNA. Neurosci Lett 1995, 199:53-56.

151. Wullner U, Loschmann PA, Weller M, Klockgether T: Apoptotic cell death in the cerebellum of mutant weaver and lurcher mice. Neurosci Lett 1995 200:109-112.

152. Kofuji $\mathrm{P}$, Hofer M, Millen KJ, Millonig JH, Davidson N, Lester HA, Hatten ME: Functional analysis of the weaver mutant GIRK2 K+ channel and rescue of weaver granule cells. Neuron 1996, 16:941-952.

153. Liesi $P$, Wright JM: Weaver granule neurons are rescued by calcium channel antagonists and antibodies against a neurite outgrowth domain of the B2 chain of laminin. J Cell Biol 1996, 134:477-486.

154. Murtomaki S, Trenkner E, Wright JM, Saksela O, Liesi P: Increased proteolytic activity of the granule neurons may contribute to neuronal death in the weaver mouse cerebellum. Dev Biol 1995, 168:635-648

155. Mecenas PE, Tsirka SE, Sallés F, Strickland S: Removal of tissue plasminogen activator does not protect against neuronal degeneration in the cerebellum of the weaver mouse. Brain Res 1997, 772:233-238.

156. Zhong J, Deng J, Phan J, Dlouhy S, Wu H, Yao W, Ye P, D'Ercole AJ, Lee WH: Insulin-like growth factor-I protects granule neurons from apoptosis and improves ataxia in weaver mice. J Neurosci Res 2005, 80:481-490.

157. Falconer DS: Two new mutants, "trembler" and "reeler," with neurological actions in the house mouse. J Genet 1951, 50:192-201.

158. Beckers MC, Bar I, Huynh-Thu T, Dernoncourt C, Brunialti AL, Montagutelli X, Guenet JL, Goffinet AM: A high-resolution genetic map of mouse chromosome 5 encompassing the reeler (rl) locus. Genomics 1994, 23:685-690.

159. D'Arcangelo G, Miao GG, Chen SC, Soares HD, Morgan Jl, Curran T: A protein related to extracellular matrix proteins deleted in the mouse mutant reeler. Nature 1995, 374:719-723.

160. Hamburgh M: Analysis of the postnatal developmental effects of "reeler," a neurological mutation in mice. A study in developmental genetics. Dev Biol 1963, 8:165-185.

161. Terashima T, Inoue K, Inoue Y, Mikoshiba K, Tsukada Y: Distribution and morphology of corticospinal tract neurons in reeler mouse cortex by the retrograde HRP method. J Comp Neurol 1983, 218:314-326.

162. Caviness VS, Sidman RL: Retrohippocampal, hippocampal and related structures of the forebrain in the reeler mutant mouse. J Comp Neurol 1973, 147:235-254.
163. Stanfield BB, Cowan WM: The morphology of the hippocampus and dentate gyrus in normal and reeler mice. J Comp Neurol 1979, 185:393-422.

164. Mikoshiba K, Kohsaka S, Takamatsu K, Aoki E, Tsukada Y: Morphological and biochemical studies on the cerebral cortex from reeler mutant mice: development of cortical layers and metabolic mapping by the deoxyglucose method. J Neurochem 1980, 34:835-844.

165. Blatt GJ1, Eisenman LM: Topographic and zonal organization of the olivocerebellar projection in the reeler mutant mouse. J Comp Neurol 1988, 267:603-615.

166. Wyss JM, Stanfield BB, Cowan WM: Structural abnormalities in the olfactory bulb of the Reeler mouse. Brain Res 1980, 188:566-571.

167. Martin MR: Morphology of the cochlear nucleus of the normal and reeler mutant mouse. J Comp Neurol 1981, 197:141-152.

168. Baba K, Sakakibara S, Setsu T, Terashima T: The superficial layers of the superior colliculus are cytoarchitectually and myeloarchitectually disorganized in the reelin-deficient mouse, reeler. Brain Res 2007, 1140:205-215

169. Kang WY, Kim SS, Cho SK, Kim S, Suh-Kim H, Lee YD: Migratory defect of mesencephalic dopaminergic neurons in developing reeler mice. Anat Cell Biol 2010, 43:241-251.

170. Devor M, Caviness VS, Derer P: A normally laminated afferent projection to an abnormally laminated cortex: some olfactory connections in the reeler mouse. J Comp Neurol 1975, 164:471-482.

171. Stanfield BB, Caviness VS Jr, Cowan WM: The organization of certain afferents to the hippocampus and dentate gyrus in normal and reeler mice. J Comp Neurol 1979, 185:461-483.

172. Lemmon $\mathrm{V}$, Pearlman AL: Does laminar position determine the receptive field properties of cortical neurons? A study of corticotectal cells in area 17 of the normal mouse and the reeler mutant. J Neurosci 1981, 1:83-93.

173. Caviness VS, Frost DO: Thalamocortical projections in the reeler mutant mouse. J Comp Neurol 1983, 219:182-202.

174. Vig J, Goldowitz D, Steindler DA, Eisenman LM: Compartmentation of the reeler cerebellum: segregation and overlap of spinocerebellar and secondary vestibulocerebellar fibers and their target cells. Neuroscience 2005, 130:735-744

175. Wagener RJ, David C, Zhao S, Haas CA, Staiger JF: The somatosensory cortex of reeler mutant mice shows absent layering but intact formation and behavioral activation of columnar somatotopic maps. J Neurosci 2010, 30:15700-15709.

176. Mariani J, Crepel F, Mikoshiba K, Changeux JP, Sotelo C: Anatomical, physiological and biochemical studies of the cerebellum from Reeler mutant mouse. Philos Trans R Soc Lond B Biol Sci 1977, 281:1-28.

177. Goffinet AM: The embryonic development of the cerebellum in normal and reeler mutant mice. Anat Embryol (Berl) 1983, 168:73-86.

178. Castagna C, Aimar P, Alasia S, Lossi L: Post-natal development of the Reeler mouse cerebellum: an ultrastructural study. Ann Anat 2013, doi: 10.1016/j.aanat.2013.11.004

179. Goffinet AM, So KF, Yamamoto M, Edwards M, Caviness VS: Architectonic and hodological organization of the cerebellum in reeler mutant mice. Brain Res 1984, 318:263-276.

180. Heckroth JA1, Goldowitz D, Eisenman LM: Purkinje cell reduction in the reeler mutant mouse: a quantitative immunohistochemical study. J Comp Neurol 1989, 279:546-555.

181. Terashima T, Inoue $K$, Inoue $Y$, Mikoshiba K, Tsukada Y: Observations on Golgi epithelial cells and granule cells in the cerebellum of the reeler mutant mouse. Brain Res 1985, 350:103-112.

182. Mikoshiba K, Terada S, Takamatsu K, Shimai K, Tsukada Y: Histochemical and immunohistochemical studies of the cerebellum from the reeler mutant mouse. Dev Neurosci 1983-1984, 6:101-110.

183. Wilson L, Sotelo C, Caviness VS: Heterologous synapses upon Purkinje cells in the cerebellum of the Reeler mutant mouse: an experimental light and electron microscopic study. Brain Res 1981, 213:63-82.

184. Dupont JL, Gardette R, Crepel F: Bioelectrical properties of cerebellar Purkinje cells in reeler mutant mice. Brain Res 1983, 274:350-353.

185. Pinto-Lord MC, Evrard P, Caviness VS: Obstructed neuronal migration along radial glial fibers in the neocortex of the reeler mouse: a Golgi-EM analysis. Brain Res 1982, 256:379-393.

186. Yuasa S1, Kitoh J, Oda S, Kawamura K: Obstructed migration of Purkinje cells in the developing cerebellum of the reeler mutant mouse. Anat Embryol (Berl) 1993, 188:317-329. 
187. Terashima T, Inoue K, Inoue Y, Yokoyama M, Mikoshiba K: Observations on the cerebellum of normal-reeler mutant mouse chimera. J Comp Neurol 1986, 252:264-278.

188. Yoshiki A, Kusakabe M: Cerebellar histogenesis as seen in identified cells of normal-reeler mouse chimeras. Int J Dev Biol 1998, 42:695-700.

189. Won SJ, Kim SH, Xie L, Wang Y, Mao XO, Jin K, Greenberg DA: Reelindeficient mice show impaired neurogenesis and increased stroke size. Exp Neurol 2006, 198:250-259.

190. Patrylo PR, Browning RA, Cranick S: Reeler homozygous mice exhibit enhanced susceptibility to epileptiform activity. Epilepsia 2006, 47:257-266.

191. Hong SE1, Shugart YY, Huang DT, Shahwan SA, Grant PE, Hourihane JO, Martin ND, Walsh CA: Autosomal recessive lissencephaly with cerebellar hypoplasia is associated with human RELN mutations. Nat Genet 2000 26:93-96.

192. Lalonde R, Hayzoun K, Derer M, Mariani J, Strazielle C: Neurobehavioral evaluation of Reln-rl-orl mutant mice and correlations with cytochrome oxidase activity. Neurosci Res 2004, 49:297-305.

193. Larson J1, Hoffman JS, Guidotti A, Costa E: Olfactory discrimination learning deficit in heterozygous reeler mice. Brain Res 2003, 971:40-46.

194. Ognibene E, Adriani W, Granstrem O, Pieretti S, Laviola G: Impulsivityanxiety-related behavior and profiles of morphine-induced analgesia in heterozygous reeler mice. Brain Res 2007, 1131:173-180.

195. Barr AM, Fish KN, Markou A, Honer WG: Heterozygous reeler mice exhibit alterations in sensorimotor gating but not presynaptic proteins. Eur $J$ Neurosci 2008, 27:2568-2574.

196. Romano E, Michetti C, Caruso A, Laviola G, Scattoni ML: Characterization of neonatal vocal and motor repertoire of reelin mutant mice. PLOS ONE 2013, 8:e64407.

197. Podhorna J, Didriksen M: The heterozygous reeler mouse: behavioural phenotype. Behav Brain Res 2004, 153:43-54.

198. Qiu S, Korwek KM, Pratt-Davis AR, Peters M, Bergman MY, Weeber EJ: Cognitive disruption and altered hippocampus synaptic function in Reelin haploinsufficient mice. Neurobiol Learn Mem 2006, 85:228-242.

199. Costa E1, Davis J, Pesold C, Tueting P, Guidotti A: The heterozygote reeler mouse as a model for the development of a new generation of antipsychotics. Curr Opin Pharmacol 2002, 2:56-62.

200. Schmitt A, Turck CW, Pilz PK, Malchow B, von Wilmsdorff M, Falkai P, Martins-de-Souza D: Proteomic similarities between heterozygous reeler mice and schizophrenia. Biol Psychiatry 2013, 74:e5-e10.

201. Krueger DD, Howell JL, Hebert BF, Olausson P, Taylor JR, Nairn AC: Assessment of cognitive function in the heterozygous reeler mouse. Psychopharmacology (Berl) 2006, 189:95-104.

202. Kutiyanawalla A, Promsote W, Terry A, Pillai A: Cysteamine treatment ameliorates alterations in GAD67 expression and spatial memory in heterozygous reeler mice. Int J Neuropsychopharmacol 2012, 15:1073-1086.

203. Romano E, Fuso A, Laviola G: Nicotine restores Wt-like levels of reelin and GAD67 gene expression in brain of heterozygous reeler mice. Neurotox Res 2013, 24:205-215.

204. Rogers JT, Zhao L, Trotter JH, Rusiana I, Peters MM, Li Q, Donaldson E, Banko JL, Keenoy KE, Rebeck GW, Hoe HS, D'Arcangelo G, Weeber EJ: Reelin supplementation recovers sensorimotor gating, synaptic plasticity and associative learning deficits in the heterozygous reeler mouse. J Psychopharmacol 2013, 27:386-395.

205. Sweet HO, Bronson RT, Johnson KR, Cook SA, Davisson MT: Scrambler, a new neurological mutation of the mouse with abnormalities of neuronal migration. Mamm Genome 1996, 7:798-802.

206. Goldowitz D, Cushing RC, Laywell E, D'Arcangelo G, Sheldon M, Sweet HO, Davisson M, Steindler D, Curran T: Cerebellar disorganization characteristic of reeler in scrambler mutant mice despite presence of reelin. J Neurosci 1997, 17:8767-8777.

207. Reeber SL, Loeschel CA, Franklin A, Sillitoe RV: Establishment of topographic circuit zones in the cerebellum of scrambler mutant mice. Front Neural Circuits 2013, 7:122

208. Jacquelin C, Strazielle C, Lalonde R: Neurologic function during developmental and adult stages in Dab1(scm) (scrambler) mutant mice. Behav Brain Res 2012, 226:265-273.

209. Jacquelin C, Lalonde R, Jantzen-Ossola C, Strazielle C: Neurobehavioral performances and brain regional metabolism in Dab1(scm) (scrambler) mutant mice. Behav Brain Res 2013, 252:92-100.

210. Lalonde R, Strazielle C: Sensorimotor learning in Dab1(scm) (scrambler) mutant mice. Behav Brain Res 2011, 218:350-352
211. Jacquelin C, Strazielle C, Lalonde R: Spontaneous alternation and spatial learning in Dab1scm (scrambler) mutant mice. Brain Res Bull 2012, 87:383-386

212. Sheldon M, Rice DS, D'Arcangelo G, Yoneshima H, Nakajima K, Mikoshiba K Howell BW, Cooper JA, Goldowitz D, Curran T: Scrambler and yotari disrupt the disabled gene and produce a reeler-like phenotype in mice. Nature 1997, 389:730-733.

213. Howell BW, Herrick TM, Cooper JA: Reelin-induced tyrosine [corrected] phosphorylation of disabled 1 during neuronal positioning. Genes Dev 1999 13:643-648.

214. Brown SD1, Nolan PM: Mouse mutagenesis-systematic studies of mammalian gene function. Hum Mol Genet 1998, 7:1627-1633.

215. Nolan PM, Peters J, Strivens M, Rogers D, Hagan J, Spurr N, Gray IC, Vizor L, Brooker D, Whitehill E, Washbourne R, Hough T, Greenaway S, Hewitt M Liu X, McCormack S, Pickford K, Selley R, Wells C, Tymowska-Lalanne Z, Roby P, Glenister P, Thornton C, Thaung C, Stevenson JA, Arkell R, Mburu P, Hardisty R, Kiernan A, Erven A, et al: A systematic, genome-wide, phenotypedriven mutagenesis programme for gene function studies in the mouse. Nat Genet 2000, 25:440-443

216. Taroni F, Chiapparini L, Mariotti C: Autosomal dominant spinocerebellar ataxias and episodic ataxias. In Handbook of the Cerebellum and Cerebella Disorders. 1st edition. Edited by Manto M, Gruol DL, Schmahmann JD, Koibuchi N, Rossi F. New York: Springer Science+Business Media; 2013:2193-2267.

217. Burright EN, Clark HB, Servadio A, Matilla T, Feddersen RM, Yunis WS, Duvick LA, Zoghbi HY, Orr HT: SCA1 transgenic mice: a model for neurodegeneration caused by an expanded CAG trinucleotide repeat. Cell 1995, 82:937-948.

218. Clark HB, Burright EN, Yunis WS, Larson S, Wilcox C, Hartman B, Matilla A, Zoghbi HY, Orr HT: Purkinje cell expression of a mutant allele of SCA1 in transgenic mice leads to disparate effects on motor behaviors, followed by a progressive cerebellar dysfunction and histological alterations. J Neurosci 1997, 17:7385-7395.

219. Klement IA, Skinner PJ, Kaytor MD, Yi H, Hersch SM, Clark HB, Zoghbi HY, Orr HT: Ataxin-1 nuclear localization and aggregation: role in polyglutamine-induced disease in SCA1 transgenic mice. Cell 1998, 95:41-53

220. Cummings $C J$, Reinstein E, Sun Y, Antalffy B, Jiang Y, Ciechanover A, Orr HT, Beaudet AL, Zoghbi HY: Mutation of the E6-AP ubiquitin ligase reduces nuclear inclusion frequency while accelerating polyglutamine-induced pathology in SCA1 mice. Neuron 1999, 24:879-892.

221. Lin X, Antalffy B, Kang D, Orr HT, Zoghbi HY: Polyglutamine expansion down-regulates specific neuronal genes before pathologic changes in SCA1. Nat Neurosci 2000, 3:157-163.

222. Huynh DP, Fiqueroa K, Hoang N, Pulst SM: Nuclear localization or inclusion body formation of ataxin- 2 are not necessary for SCA2 pathogenesis in mouse or human. Nat Genet 2000, 26:44-50.

223. Aguiar J, Fernandez J, Aguilar A, Mendoza Y, Vazquez M, Suarez J, Berlanga J, Cruz S, Guillen G, Herrera L, Velazquez L, Santos N, Merino N: Ubiquitous expression of human SCA2 gene under the regulation of the SCA2 self promoter cause specific Purkinje cell degeneration in transgenic mice. Neurosci Lett 2010, 392:202-206

224. Hansen ST, Meera P, Otis TS, Pulst SM: Changes in Purkinje cell firing and gene expression precede behavioral pathology in a mouse model of SCA2. Hum Mol Genet 2013, 22:271-283.

225. Riess O, Laccone FA, Gispert S, Schols L, Zuhlke C, Vieira-Saecker AM, Herlt S, Wessel K, Epplen JT, Weber BH, Kreuz F, Chahrokh-Zadeh S, Meindl A, Lunkes A, Aguiar J, Macek M Jr, Krebsova A, Macek M Sr, Burk K, Tinschert S, Schreyer I, Pulst SM, Auburger G: SCA2 trinucleotide expansion in German SCA patients. Neurogenetics 1997, 1:59-64.

226. Liu J, Tang TS, Tu H, Nelson O, Herndon E, Huynh DP, Pulst SM, Bezprozvanny I: Deranged calcium signaling and neurodegeneration in spinocerebellar ataxia type 2. J Neurosci 2009, 29:9148-9162.

227. Cemal CK, Carroll CJ, Lawrence L, Lowrie MB, Ruddle P, Al-Mahdawi S, King RH, Pook MA, Huxley C, Chamberlain S: YAC transgenic mice carrying pathological alleles of the MJD1 locus exhibit a mild and slowly progressive cerebellar deficit. Hum Mol Genet 2002, 11:1075-1094.

228. Chou AH, Yeh TH, Ouyang P, Chen YL, Chen SY, Wang HL: Polyglutamineexpanded ataxin-3 causes cerebellar dysfunction of SCA3 transgenic mice by inducing transcriptional dysregulation. Neurobiol Dis 2008, 31:89-101. 
229. Chou AH, Chen SY, Yeh TH, Weng YH, Wang HL: HDAC inhibitor sodium butyrate reverses transcriptional downregulation and ameliorates ataxic symptoms in a transgenic mouse model of SCA3. Neurobiol Dis 2011, 41:481-488.

230. Shakkottai VG, do Carmo Costa M, Dell'Orco JM, Sankaranarayanan A, Wulff H, Paulson HL: Early changes in cerebellar physiology accompany motor dysfunction in the polyglutamine disease spinocerebellar ataxia type 3. J Neurosci 2011, 31:13002-13014.

231. Hubener J, Weber JJ, Richter C, Honold L, Weiss A, Murad F, Breuer P, Wullner U, Bellstedt P, Paquet-Durand F, Takano J, Saido TC, Riess O, Nguyen HP: Calpain-mediated ataxin-3 cleavage in the molecular pathogenesis of spinocerebellar ataxia type 3 (SCA3). Hum Mol Genet 2013, 22:508-518.

232. Konno A, Shuvaev AN, Miyake N, Miyake K, lizuka A, Matsuura S, Huda F, Nakamura K, Yanagi S, Shimada T, Hirai H: Mutant ataxin-3 with an abnormally expanded polyglutamine chain disrupts dendritic development and metabotropic glutamate receptor signaling in mouse cerebellar purkinje cells. Cerebellum 2014, 13:29-41.

233. Nguyen HP, Hubener J, Weber JJ, Grueninger S, Riess O, Weiss A: Cerebellar soluble mutant ataxin-3 level decreases during disease progression in Spinocerebellar Ataxia Type 3 mice. PLOS ONE 2013, 8:e62043.

234. Boy J, Schmidt T, Wolburg H, Mack A, Nuber S, Böttcher M, Schmitt I, Holzmann C, Zimmermann F, Servadio A, Riess O: Reversibility of symptoms in a conditional mouse model of spinocerebellar ataxia type 3. Hum Mol Genet 2009, 18:4282-4295

235. Nobrega C, Nascimento-Ferreira I, Onofre I, Albuquerque D, Hirai H, Deglon N, de Almeida LP: Silencing mutant ataxin-3 rescues motor deficits and neuropathology in Machado-Joseph disease transgenic mice. PLOS ONE 2013, 8:e52396.

236. Rodriguez-Lebron E, Costa M, Luna-Cancalon K, Peron TM, Fischer S, Boudreau RL, Davidson BL, Paulson HL: Silencing mutant ATXN3 expression resolves molecular phenotypes in SCA3 transgenic mice. Mol Ther 2013, 21:1909-1918.

237. Wang HL, Hu SH, Chou AH, Wang SS, Weng YH, Yeh TH: H1152 promotes the degradation of polyglutamine-expanded ataxin-3 or ataxin-7 independently of its ROCK-inhibiting effect and ameliorates mutant ataxin-3-induced neurodegeneration in the SCA3 transgenic mouse. Neuropharmacology 2013, 70:1-11.

238. Zhuchenko O, Bailey J, Bonnen P, Ashizawa T, Stockton DW, Amos C, Dobyns WB, Subramony SH, Zoghbi HY, Lee CC: Autosomal dominant cerebellar ataxia (SCA6) associated with small polyglutamine expansions in the alpha 1A-voltage-dependent calcium channel. Nat Genet 1997, 15:62-69.

239. Green MC, Sidman RL: Tottering - a neuromuscular mutation in the mouse. And its linkage with oligosyndactylism. J Hered 1962, 53:233-237.

240. Ebner TJ, Chen G: Tottering mouse. In Handbook of the Cerebellum and Cerebellar Disorders. 1st edition. Edited by Manto M, Gruol DL, Schmahmann JD, Koibuchi N, Rossi F. New York: Springer Science +Business Media; 2013:1521-1540.

241. Doyle J, Ren X, Lennon G, Stubbs L: Mutations in the Cacnl1a4 calcium channel gene are associated with seizures, cerebellar degeneration, and ataxia in tottering and leaner mutant mice. Mamm Genome 1997, 8:113-120.

242. Zwingman TA, Neumann PE, Noebels $J$, Herrup K: Rocker is a new variant of the voltage-dependent calcium channel gene Cacna1a. J Neurosci 2001, 21:1169-1178.

243. Watase K, Barrett CF, Miyazaki T, Ishiguro T, Ishikawa K, Hu Y, Unno T, Sun Y, Kasai S, Watanabe M, Gomez CM, Mizusawa H, Tsien RW, Zoghbi HY: Spinocerebellar ataxia type 6 knockin mice develop a progressive neuronal dysfunction with age-dependent accumulation of mutant CaV2.1 channels. Proc Natl Acad Sci USA 2008, 105:11987-11992.

244. Saegusa H, Wakamori M, Matsuda Y, Wang J, Mori Y, Zong S, Tanabe T: Properties of human Cav2.1 channel with a spinocerebellar ataxia type 6 mutation expressed in Purkinje cells. Mol Cell Neurosci 2007, 34:261-270.

245. Hoebeek FE, Stahl JS, van Alphen AM, Schonewille M, Luo C, Rutteman M, van den Maagdenberg AM, Molenaar PC, Goossens HH, Frens MA, De Zeeuw Cl: Increased noise level of purkinje cell activities minimizes impact of their modulation during sensorimotor control. Neuron 2005, 45:953-965.

246. Yvert G, Lindenberg KS, Picaud S, Landwehrmeyer GB, Sahel JA, Mandel JL: Expanded polyglutamines induce neurodegeneration and trans-neuronal alterations in cerebellum and retina of SCA7 transgenic mice. Hum Mol Genet 2000, 9:2491-2506.

247. Yoo SY, Pennesi ME, Weeber EJ, Xu B, Atkinson R, Chen S, Armstrong DL, Wu SM, Sweatt JD, Zoghbi HY: SCA7 knockin mice model human SCA7 and reveal gradual accumulation of mutant ataxin-7 in neurons and abnormalities in short-term plasticity. Neuron 2003, 37:383-401.

248. Garden GA, Libby RT, Fu YH, Kinoshita Y, Huang J, Possin DE, Smith AC, Martinez RA, Fine GC, Grote SK, Ware CB, Einum DD, Morrison RS, Ptacek LJ, Sopher BL, La Spada AR: Polyglutamine-expanded ataxin-7 promotes non-cell-autonomous purkinje cell degeneration and displays proteolytic cleavage in ataxic transgenic mice. J Neurosci 2002, 22:4897-4905.

249. Chou AH, Chen CY, Chen SY, Chen WJ, Chen YL, Weng YS, Wang HL: Polyglutamine-expanded ataxin-7 causes cerebellar dysfunction by inducing transcriptional dysregulation. Neurochem Int 2010, 56:329-339.

250. Furrer SA, Waldherr SM, Mohanachandran MS, Baughn TD, Nguyen KT, Sopher BL, Damian VA, Garden GA, La Spada AR: Reduction of mutant ataxin-7 expression restores motor function and prevents cerebellar synaptic reorganization in a conditional mouse model of SCA7. Hum Mol Genet 2013, 22:890-903.

251. Chort A, Alves S, Marinello M, Dufresnois B, Dornbierer JG, Tesson C, Latouche M, Baker DP, Barkats M, El Hachimi KH, Ruberg M, Janer A, Stevanin $G$, Brice $A$, Sittler $A$ : Interferon $\beta$ induces clearance of mutant ataxin 7 and improves locomotion in SCA7 knock-in mice. Brain 2013, 136:1732-1745.

252. Wang Z, Gardell LR, Ossipov MH, Vanderah TW, Brennan MB, Hochgeschwender U, Hruby VJ, Malan TP Jr, Lai J, Porreca F: Pronociceptive actions of dynorphin maintain chronic neuropathic pain. J Neurosci 2001, 21:1779-1786.

253. Watanabe H, Mizoguchi H, Verbeek DS, Kuzmin A, Nyberg F, Krishtal O, Sakurada S, Bakalkin G: Non-opioid nociceptive activity of human dynorphin mutants that cause neurodegenerative disorder spinocerebellar ataxia type 23. Peptides 2012, 35:306-310.

254. Koide R, Ikeuchi T, Onodera O, Tanaka H, Igarashi S, Endo K, Takahashi H, Kondo R, Ishikawa A, Hayashi T, Saito M, Tomoda A, Miike T, Naito H, Ikuta F, Tsuji S: Unstable expansion of CAG repeat in hereditary dentatorubralpallidoluysian atrophy (DRPLA). Nat Genet 1994, 6:9-13.

255. Sato T, Oyake M, Nakamura K, Nakao K, Fukusima Y, Onodera O, Igarashi S, Takano H, Kikugawa K, Ishida Y, Shimohata T, Koide R, Ikeuchi T, Tanaka H, Futamura N, Matsumura R, Takayanagi T, Tanaka F, Sobue G, Komure O, Takahashi M, Sano A, Ichikawa Y, Goto J, Kanazawa I, Katsuki M, Tsuji S: Transgenic mice harboring a full-length human mutant DRPLA gene exhibit age-dependent intergenerational and somatic instabilities of CAG repeats comparable with those in DRPLA patients. Hum Mol Genet 1999, 8:99-106.

256. Sato T, Miura M, Yamada M, Yoshida T, Wood JD, Yazawa I, Masuda M, Suzuki T, Shin RM, Yau HJ, Liu FC, Shimohata T, Onodera O, Ross CA, Katsuki M, Takahashi H, Kano M, Aosaki T, Tsuji S: Severe neurological phenotypes of Q129 DRPLA transgenic mice serendipitously created by en masse expansion of CAG repeats in Q76 DRPLA mice. Hum Mol Genet 2009, 18:723-736.

257. Suzuki K, Sato T, Yamada M, Takahashi H, Tsuji S: DRPLA: recent advances in research using transgenic mouse models. Methods Mol Biol 2013, 1010:277-292.

258. Suzuki K, Zhou J, Sato T, Takao K, Miyagawa T, Oyake M, Yamada M, Takahashi H, Takahashi Y, Goto J, Tsuji S: DRPLA transgenic mouse substrains carrying single copy of full-length mutant human DRPLA gene with variable sizes of expanded CAG repeats exhibit CAG repeat length- and age-dependent changes in behavioral abnormalities and gene expression profiles. Neurobiol Dis 2012, 46:336-350.

259. Miyawaki S, Mitsuoka S, Sakiyama T, Kitagawa T: Sphingomyelinosis, a new mutation in the mouse: a model of Niemann-Pick disease in humans. J Hered 1982, 73:257-263.

260. Tanaka J, Nakamura H, Miyawaki S: Cerebellar involvement in murine sphingomyelinosis: a new model of Niemann-Pick disease. J Neuropathol Exp Neurol 1988, 47:291-300.

261. Maue RA, Burgess RW, Wang B, Wooley CM, Seburn KL, Vanier MT, Rogers MA, Chang CC, Chang TY, Harris BT, Graber DJ, Penatti CA, Porter DM, Szwergold BS, Henderson LP, Totenhagen JW, Trouard TP, Borbon IA, Erickson RP: A novel mouse model of Niemann-Pick type C disease carrying a D1005G-Npc1 mutation comparable to commonly observed human mutations. Hum Mol Genet 2012, 21:730-750. 
262. Voikar V, Rauvala H, Ikonen E: Cognitive deficit and development of motor impairment in a mouse model of Niemann-Pick type $C$ disease. Behav Brain Res 2002, 132:1-10

263. Hovakimyan M1, Maass F, Petersen J, Holzmann C, Witt M, Lukas J, Frech MJ, Hübner R, Rolfs A, Wree A: Combined therapy with cyclodextrin/ allopregnanolone and miglustat improves motor but not cognitive functions in Niemann-Pick Type C1 mice. Neuroscience 2013, 252:201-211.

264. Lopez ME, Klein AD, Dimbil UJ, Scott MP: Anatomically defined neuronbased rescue of neurodegenerative Niemann-Pick type $C$ disorder. $J$ Neurosci 2011, 31:4367-4378.

265. Byun K, Kim D, Bayarsaikhan E, Oh J, Kim J, Kwak G, Jeong GB, Jo SM, Lee B: Changes of calcium binding proteins, c-Fos and COX in hippocampal formation and cerebellum of Niemann-Pick, type $C$ mouse. J Chem Neuroanat 2013, 52:1-8.

266. Seo Y, Shin Y, Kim HS, Kang I, Hong IS, Choi SW, Yu KR, Kang KS: Donepezil enhances Purkinje cell survival and alleviates motor dysfunction by inhibiting cholesterol synthesis in a murine model of Niemann pick disease type C. J Neuropathol Exp Neurol 2014, in press.

267. Bae JS, Furuya S, Ahn SJ, Yi SJ, Hirabayashi Y, Jin HK: Neuroglial activation in Niemann-Pick Type $C$ mice is suppressed by intracerebral transplantation of bone marrow-derived mesenchymal stem cells. Neurosci Lett 2005, 381:234-236.

268. Bae JS, Han HS, Youn DH, Carter JE, Modo M, Schuchman EH, Jin HK: Bone marrow-derived mesenchymal stem cells promote neuronal networks with functional synaptic transmission after transplantation into mice with neurodegeneration. Stem Cells 2007, 25:1307-1316.

269. Bae JS, Carter JE, Jin HK: Adipose tissue-derived stem cells rescue Purkinje neurons and alleviate inflammatory responses in Niemann-Pick disease type C mice. Cell Tissue Res 2010, 340:357-369.

270. Lee H, Lee JK, Min WK, Bae JH, He X, Schuchman EH, Bae JS, Jin HK: Bone marrow-derived mesenchymal stem cells prevent the loss of NiemannPick type $\mathrm{C}$ mouse Purkinje neurons by correcting sphingolipid metabolism and increasing sphingosine-1-phosphate. Stem Cells 2010, 28:821-831.

271. Noreau A, Dupre N, Bouchard JP, Dion PA, Rouleau GA: Autosomal recessive cerebellar ataxias. In Handbook of the Cerebellum and Cerebellar Disorders. 1st edition. Edited by Manto M, Gruol DL, Schmahmann JD, Koibuchi N, Rossi F, New York: Springer Science+Business Media; 2013:2177-2191.

272. Al-Mahdawi S, Pinto RM, Varshney D, Lawrence L, Lowrie MB, Hughes S, Webster Z, Blake J, Cooper JM, King R, Pook MA: GAA repeat expansion mutation mouse models of Friedreich ataxia exhibit oxidative stress leading to progressive neuronal and cardiac pathology. Genomics 2006, 88:580-590.

273. Miranda CJ, Santos MM, Ohshima K, Smith J, Li L, Bunting M, Cossee M, Koenig M, Sequeiros J, Kaplan J, Pandolfo M: Frataxin knockin mouse. FEBS Lett 2002, 512:291-297.

274. Sabatier C, Plump AS, Le M, Brose K, Tamada A, Murakami F, Lee EY, Tessier-Lavigne M: The divergent Robo family protein rig-1/Robo3 is a negative regulator of slit responsiveness required for midline crossing by commissural axons. Cell 2004, 117:157-169.

275. Marillat V, Sabatier C, Failli V, Matsunaga E, Sotelo C, Tessier-Lavigne M, Chédotal A: The slit receptor Rig-1/Robo3 controls midline crossing by hindbrain precerebellar neurons and axons. Neuron 2004, 43:69-79.

276. Di Meglio T, Nguyen-Ba-Charvet KT, Tessier-Lavigne M, Sotelo C, Chedotal A: Molecular mechanisms controlling midline crossing by precerebellar neurons. J Neurosci 2008, 28:6285-6294

277. Tamada A, Kumada T, Zhu Y, Matsumoto T, Hatanaka Y, Muguruma K, Chen Z, Tanabe Y, Torigoe M, Yamauchi K, Oyama H, Nishida K, Murakami F: Crucial roles of Robo proteins in midline crossing of cerebellofugal axons and lack of their up-regulation after midline crossing. Neural Dev 2008, 3:29.

278. Jen JC, Chan WM, Bosley TM, Wan J, Carr JR, Rüb U, Shattuck D, Salamon G, Kudo LC, Ou J, Lin DD, Salih MA, Kansu T, Al Dhalaan H, Al Zayed Z, MacDonald DB, Stigsby B, Plaitakis A, Dretakis EK, Gottlob I, Pieh C, Traboulsi El, Wang Q, Wang L, Andrews C, Yamada K, Demer JL, Karim S, Alger JR, Geschwind DH, et al: Mutations in a human ROBO gene disrupt hindbrain axon pathway crossing and morphogenesis. Science 2004, 304:1509-1513.

279. Jen J, Coulin CJ, Bosley TM, Salih MA, Sabatti C, Nelson SF, Baloh RW: Familial horizontal gaze palsy with progressive scoliosis maps to chromosome 11q23-25. Neurology 2002, 59:432-435.
280. Renier N, Schonewille M, Giraudet F, Badura A, Tessier-Lavigne M, Avan P, De Zeeuw Cl, Chedotal A: Genetic dissection of the function of hindbrain axonal commissures. PLOS Biol 2010, 8:e1000325

281. Badura A, Schonewille M, Voges K, Galliano E, Renier N, Gao Z, Witter L, Hoebeek FE, Chédotal A, De Zeeuw Cl: Climbing fiber input shapes reciprocity of Purkinje cell firing. Neuron 2013, 78:700-713.

282. Porras-Garcia ME, Ruiz R, Perez-Villegas EM, Armengol JA: Motor learning of mice lacking cerebellar Purkinje cells. Front Neuroanat 2013, 7: doi: 10.3389/fnana.2013.00004.

283. Sanchez-Campusano R, Gruart A, Delgado-Garcia JM: Dynamic changes in the cerebellar-interpositus/red-nucleus-motoneuron pathway during motor learning. Cerebellum 2011, 10:702-710.

284. Chen L, Bao S, Thompson RF: Bilateral lesions of the interpositus nucleus completely prevent eyeblink conditioning in Purkinje cell-degeneration mutant mice. Behav Neurosci 1999, 113:204-210.

285. Koekkoek SK, Yamaguchi K, Milojkovic BA, Dortland BR, Ruigrok TJ, Maex R, De Graaf W, Smit AE, VanderWerf F, Bakker CE, Willemsen R, Ikeda T, Kakizawa S, Onodera K, Nelson DL, Mientjes E, Joosten M, De Schutter E, Oostra BA, Ito M, De Zeeuw Cl: Deletion of FMR1 in Purkinje cells enhances parallel fiber LTD, enlarges spines, and attenuates cerebellar eyelid conditioning in Fragile X syndrome. Neuron 2005, 47:339-352.

286. Gerwig M, Hajjar K, Dimitrova A, Maschke M, Kolb FP, Frings M, Thilmann AF, Forsting M, Diener HC, Timmann D: Timing of conditioned eyeblink responses is impaired in cerebellar patients. J Neurosci 2005, 25:3919-3931.

287. Thieme A, Thürling M, Galuba J, Burciu RG, Göricke S, Beck A, Aurich V, Wondzinski E, Siebler M, Gerwig M, Bracha V, Timmann D: Storage of a naturally acquired conditioned response is impaired in patients with cerebellar degeneration. Brain 2013, 136:2063-2076.

288. Ritvo ER, Freeman BJ, Scheibel AB, Duong T, Robinson H, Guthrie D, Ritvo A: Lower Purkinje cell counts in the cerebella of four autistic subjects: initial findings of the UCLA-NSAC autopsy research report. Am J Psychiatry 1986, 143:862-866.

289. Courchesne E, Hesselink JR, Jernigan TL, Yeung-Courchesne R: Abnormal neuroanatomy in a nonretarded person with autism. Unusual findings with magnetic resonance imaging. Arch Neurol 1987, 44:335-341.

290. Courchesne $E$, Yeung-Courchesne $R$, Press GA, Hesselink JR, Jernigan TL: Hypoplasia of cerebellar vermal lobules VI and VII in autism. N Engl J Med 1988, 318:1349-1354.

291. Becker EB, Stoodley CJ: Autism spectrum disorder and the cerebellum. Int Rev Neurobiol 2013, 113:1-34.

292. Whitney ER, Kemper TL, Rosene DL, Bauman ML, Blatt GJ: Density of cerebellar basket and stellate cells in autism: evidence for a late developmental loss of Purkinje cells. J Neurosci Res 2009, 87:2245-2254.

293. Martin LA, Goldowitz D, Mittleman G: Repetitive behavior and increased activity in mice with Purkinje cell loss: a model for understanding the role of cerebellar pathology in autism. Eur J Neurosci 2010, 31:544-555.

294. Laviola G, Ognibene E, Romano E, Adriani W, Keller F: Gene-environment interaction during early development in the heterozygous reeler mouse: clues for modelling of major neurobehavioral syndromes. Neurosci Biobehav Rev 2009, 33:560-572.

295. Baudouin SJ, Gaudias J, Gerharz S, Hatstatt L, Zhou K, Punnakkal P, Tanaka KF, Spooren W, Hen R, De Zeeuw Cl, Vogt K, Scheiffele P: Shared synaptic pathophysiology in syndromic and nonsyndromic rodent models of autism. Science 2012, 338:128-132.

296. De Zeeuw Cl, Hoebeek FE, Bosman LW, Schonewille M, Witter L, Koekkoek SK: Spatiotemporal firing patterns in the cerebellum. Nat Rev Neurosci 2011, 12:327-344.

297. Chen X, Kovalchuk Y, Adelsberger H, Henning HA, Sausbier M, Wietzorrek G, Ruth $\mathrm{P}$, Yarom Y, Konnerth A: Disruption of the olivo-cerebellar circuit by Purkinje neuron-specific ablation of BK channels. Proc Natl Acad Sci USA 2010, 107:12323-12328.

298. Schiffmann SN, Cheron G, Lohof A, d'Alcantara P, Meyer M, Parmentier M, Schurmans S: Impaired motor coordination and Purkinje cell excitability in mice lacking calretinin. Proc Natl Acad Sci USA 1999, 96:5257-5262.

299. Bearzatto B, Servais L, Roussel C, Gall D, Baba-Aissa F, Schurmans S, de Kerchove d'Exaerde A, Cheron G, Schiffmann SN: Targeted calretinin expression in granule cells of calretinin-null mice restores normal cerebellar functions. FASEB J 2006, 20:380-382.

300. Gao Z, van Beugen BJ, De Zeeuw Cl: Distributed synergistic plasticity and cerebellar learning. Nat Rev Neurosci 2012, 13:619-635. 
301. Sotelo C, Alvarado-Mallart RM: Embryonic and adult neurons interact to allow Purkinje cell replacement in mutant cerebellum. Nature 1987, 327:421-423.

302. Sotelo C, Alvarado-Mallart RM: Growth and differentiation of cerebellar suspensions transplanted into the adult cerebellum of mice with heredodegenerative ataxia. Proc Natl Acad Sci USA 1986, 83:1135-1139.

303. Sotelo C, Alvarado-Mallart RM: The reconstruction of cerebellar circuits. Trends Neurosci 1991, 14:350-355.

304. Sotelo C, Alvarado-Mallart RM: Reconstruction of the defective cerebellar circuitry in adult Purkinje cell degeneration mutant mice by Purkinje cell replacement through transplantation of solid embryonic implants. Neuroscience 1987, 20:1-22.

305. Triarhou LC, Low WC, Ghetti B: Intraparenchymal grafting of cerebellar cell suspensions to the deep cerebellar nuclei of pcd mutant mice, with particular emphasis on re-establishment of a Purkinje cell cortico-nuclear projection. Anat Embryol (Berl) 1992, 185:409-420.

306. Keep M, Alvarado-Mallart RM, Sotelo C: New insight on the factors orienting the axonal outgrowth of grafted Purkinje cells in the pcd cerebellum. Dev Neurosci 1992, 14:153-165.

307. Carletti B, Williams IM, Leto K, Nakajima K, Magrassi L, Rossi F: Time constraints and positional cues in the developing cerebellum regulate Purkinje cell placement in the cortical architecture. Dev Biol 2008, 317:147-160.

308. Carletti B, Rossi F: Selective rather than inductive mechanisms favour specific replacement of Purkinje cells by embryonic cerebellar cells transplanted to the cerebellum of adult Purkinje cell degeneration (pcd) mutant mice. Eur J Neurosci 2005, 22:1001-1012.

309. Triarhou LC, Zhang W, Lee WH: Graft-induced restoration of function in hereditary cerebellar ataxia. Neuroreport 1995, 6:1827-1832.

310. Triarhou LC, Zhang W, Lee WH: Amelioration of the behavioral phenotype in genetically ataxic mice through bilateral intracerebellar grafting of fetal Purkinje cells. Cell Transplant 1996, 5:269-277.

311. Dumesnil-Bousez N, Sotelo C: Partial reconstruction of the adult Lurcher cerebellar circuitry by neural grafting. Neuroscience 1993, 55:1-21.

312. Heckroth JA, Hobart NJH, Summers D: Transplanted neurons alter the course of neurodegenerative disease in Lurcher mutant mice. Exp Neurol 1998, 154:336-352.

313. Tomey DA, Heckroth JA: Transplantation of normal embryonic cerebellar cell suspensions into the cerebellum of Lurcher mutant mice. Exp Neurol 1993, 122:165-170.

314. Cendelin J, Babuska V, Korelusova I, Houdek Z, Vozeh F: Long-term survival of solid embryonic cerebellar grafts in Lurcher mice. Neurosci Lett 2012, 515:23-27.

315. Jones J, Jaramillo-Merchan J, Bueno C, Pastor D, Viso-Leon M, Martinez S: Mesenchymal stem cells rescue Purkinje cells and improve motor functions in a mouse model of cerebellar ataxia. Neurobiol Dis 2010, 40:415-423.

316. Li J, Imitola J, Snyder EY, Sidman RL: Neural stem cells rescue nervous purkinje neurons by restoring molecular homeostasis of tissue plasminogen activator and downstream targets. J Neurosci 2006, 26:7839-7848

317. Kohsaka S, Takayama H, Ueda T, Toya S, Tsukada Y: Reorganization of cerebellar cell suspension transplanted into the weaver mutant cerebellum and immunohistochemical detection of synaptic formation. Neurosci Res 1988, 6:162-166.

318. Kaemmerer WF, Low WC: Cerebellar allografts survive and transiently alleviate ataxia in a transgenic model of spinocerebellar ataxia Type-1. Exp Neurol 1999, 158:301-311.

319. Chintawar S, Hourez R, Ravella A, Gall D, Orduz D, Rai M, Bishop DP, Genua S, Schiffmann SN, Pandolfo M: Grafting neural precursor cells promotes functional recovery in an SCA1 mouse model. J Neurosci 2009, 29:13126-13135.

320. Matsuura S, Shuvaev AN, lizuka A, Nakamura K, Hirai H: Mesenchymal stem cells ameliorate cerebellar pathology in a mouse model of spinocerebellar ataxia type 1. Cerebellum 2013, doi:10.1007/s12311-013-0536-1.

321. Chang YK, Chen MH, Chiang YH, Chen YF, Ma WH, Tseng CY, Soong BW, $\mathrm{Ho} \mathrm{JH}$, Lee OK: Mesenchymal stem cell transplantation ameliorates motor function deterioration of spinocerebellar ataxia by rescuing cerebellar Purkinje cell. J Biomed Sci 2011, 18:54.

322. Tian ZM, Chen T, Zhong N, Li ZC, Yin F, Liu S: Clinical study of transplantation of neural stem cells in therapy of inherited cerebellar atrophy. Beijing Da Xue Xue Bao 2009, 41:456-458.
323. Lee PH, Lee JE, Kim HS, Song SK, Lee HS, Nam HS, Cheong JW, Jeong Y, Park HJ, Kim DJ, Nam CM, Lee JD, Kim HO, Sohn YH: A randomized trial of mesenchymal stem cells in multiple system atrophy. Ann Neurol 2012, 72:32-40.

324. Wassef M, Sotelo C, Cholley B, Brehier A, Thomasset M: Cerebellar mutations affecting the postnatal survival of Purkinje cells in the mouse disclose a longitudinal pattern of differentially sensitive cells. Dev Biol 1987, 124:379-389.

doi:10.1186/2053-8871-1-4

Cite this article as: Cendelin: From mice to men: lessons from mutant ataxic mice. Cerebellum \& Ataxias 2014 1:4

\section{Submit your next manuscript to BioMed Central and take full advantage of:}

- Convenient online submission

- Thorough peer review

- No space constraints or color figure charges

- Immediate publication on acceptance

- Inclusion in PubMed, CAS, Scopus and Google Scholar

- Research which is freely available for redistribution 